\title{
中期更新世の古浜名湾における古環境の時間的・空間的変化 一貝形虫化石群集と全有機炭素・全窒素・全イオウ分析結果一
}

Temporal and spatial variations of paleoenvironments of Paleo-Hamana Bay, central Japan, during the Middle Pleistocene - Analyses of fossil ostracode assemblages, and total organic carbon, total nitrogen and total sulfur contents -

\section{入月俊明 * 瀬戸浩二 **}

Toshiaki Irizuki* and Koji Seto**

2004 年 1 月 16 日受付.

2004 年 3 月 9 日受理.

* 島根大学総合理工学部地球資源環境学科

Department of Geoscience, Faculty of Science and Engineering, Shimane University, 1060 Nishikawatsu, Matsue 690-8504, Japan

** 島根大学汽水域研究センター

Research Center for Coastal Lagoon Environments, Shimane University, 1060 Nishikawatsu, Matsue 690-8504, Japan

\section{Abstract}

High-resolution analyses of fossil ostracode assemblages, and total organic carbon (TOC), total nitrogen (TN) and total sulfur (TS) contents were conducted in four sites exposing the Sahama Mud Member of the Middle Pleistocene Hamamatsu Formation, central Japan, to infer paleoenvironments of Paleo-Hamana Bay. Twenty-six ostracode species are included in 84 samples. Neomonoceratina delicata is the most dominant species. It is not recognized in modern similar environments in Japanese islands except for Ryukyu islands, but is living abundantly in the South China Sea. Spinileberis quadriaculeata, Bicornucythere bisanensis, Pistocythereis bradyi and Bicornucythere sp. are also abundant, and they are common and widely distributed in Japanese inner to middle enclosed muddy bays. Relative frequency of those five species reaches $98.3 \%$.

On the basis of the results of fossil ostracode and TOC, TN and TS analyses, temporal and spacial variations of paleoenvironments of Paleo-Hamana Bay are reconstructed as follows. An enclosed brackish shallow bay was formed during an early transgression and oxygen-poor bottom waters developed. After that warm water widely invaded the study sites and the bay changed to slightly oxygen-rich conditions. The bay became enclosed again and water depth reached the maximum (around $10 \mathrm{~m}$ deep at the deepest) at the central part of the study sites during the rapid increase of the sea level. At the early time of the highstand of the sea level, the bay was extremely enclosed and relative contribution of non-marine and /or terrestrial organic materials to the bay sediments increased temporarily. As a result a parallel laminated clay suggesting anoxic environments, was widely developed. Afterward, the bay became shallower under the influence of waters warmer than today.

Thus, Paleo-Hamana Bay in the middle Pleistocene was mostly enclosed bay and salinity during the transgression and the highstand of the sea level was higher than that in present-day Hamana-ko Bay.

Key words: Hamamatsu Formation, Sahama Mud Member, Paleo-Hamana Bay, Middle Pleistocene, Ostracoda, TOC, TN, TS

\section{は じめに}

\section{静岡県西部に位置する浜名湖の起源や後水期の地史は地質} 学, 堆積学, 地形学, 地球化学, 古生物学を統合した研究に より詳細に復元されている（池谷ほか, 1990; 南ほか, 1995). それらによると現在の浜名湖は縄文海進により形成された内 湾が, 3000 年前頃から完全に淡水化し, その後, 1498 年の 津波とその翌年の暴風により, 湾口部である今切口が決壊し, 再び本格的に海水が侵入した海跡湖である.このような浜名 湖の東岸地域には中期更新世以降, 水河性海水準変動による
海進の結果, 汽水成〜海成堆積物が断続的に堆積しており, 現在の浜名湖と類似した内湾 (古浜名湾) が中一後期更新世 にも存在していたと考えられている（例えば,土, 1960; 小林, 1964). 本研究対象である中部更新統浜松層中の佐浜泥層 （土，1960）は, このような堆積物の 1 つで, ナウマンゾウ (Paleoloxodon naumanni) 化石の完模式標本が記載され た地層として有名である (Makiyama, 1924; Takai and Tsuchi, 1959; 野嶋ほか, 2003; 高橋ほか, 2003).この地層 は主として層厚 $20 \mathrm{~m}$ 以下の青灰色塊状泥からなり, 多くの 種類の化石を含み，これらに基づいた古環境の概要は明らか 


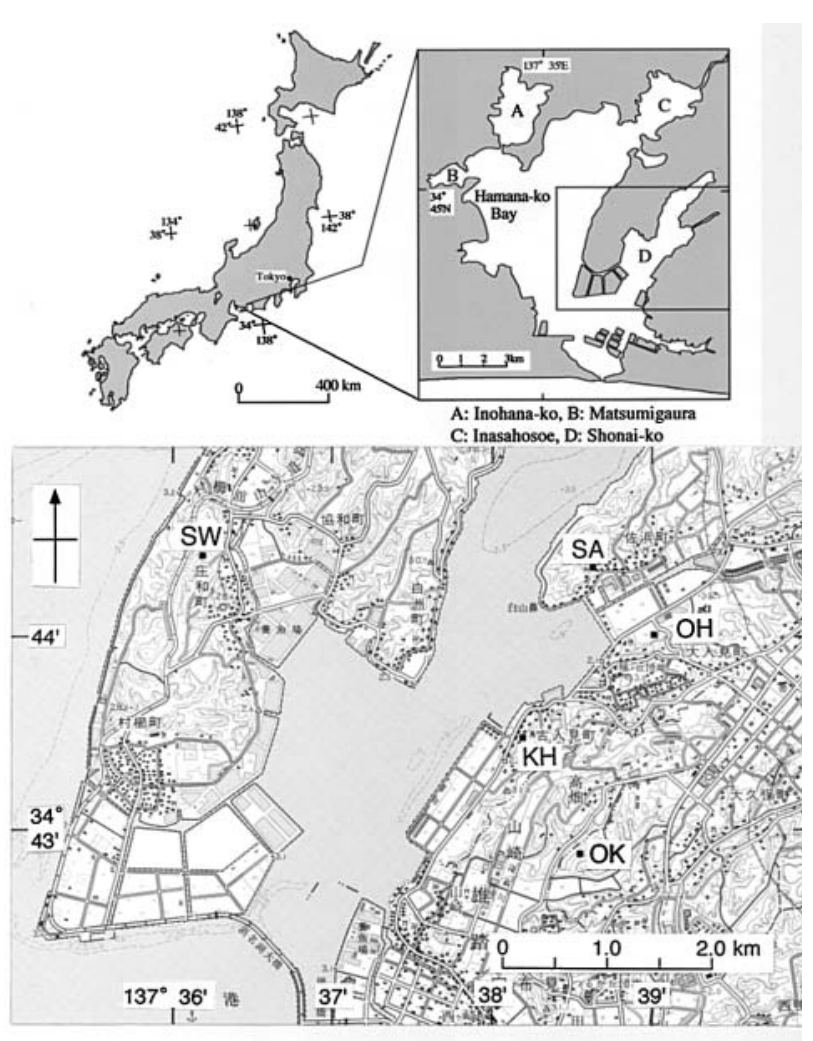

Fig.1. Maps showing sampling sites. Base map: 1:50,000 topographical map "Hamamatsu" by the Geographical Survey Institute of Japan.

にされている（例えば, 土，1960）が，相対的海水準変動と 古浜名湾の海洋環境との密接な関係が高時間・空間分解能で 検討されていない。 また，佐浜泥層は基本的に塊状泥からな つているために, 堆積相解析では詳細な古環境が復元されに くい. そこで, 本研究では, このような均質な泥質堆積物か らできるだけ高密度な試料採取を行い，それらに含まれてい る微小甲殼類の貝形虫化石を抽出した. さらに堆積物中の全 有機炭素 (TOC) ・ 全窒素 (TN) ・ 全イオウ (TS) 含有率を 測定し (CNS 元素分析), これらの解析結果を統合して, 古 生物学的, 地球化学的な観点から中期更新世における古浜名 湾の海洋環境を復元をした.

\section{浜名湖東岸地域の地質}

浜名湖の東岸（Fig.1）に広がる三方が原台地の地質は, 古くから多くの研究者によって調査されてきた（例えば, 小 林, 1942, 1964; 土, 1960; 磯見・井上, 1972; 武藤, 1987; 杉 山, 1991)。小林（1964）は浜松市周辺の地質を調查し，浜 松層（郷原・佐々木, 1951 命名）を，下部層と上部層に区分 したが，両者の関係は整合か不整合か不明であるとした。ま た，上部層を佐浜相（主として海成泥層）と鴨江相（主とし て河成碟層）とに区分し，両者の関係は同時異相であると考 えた. 武藤（1987）は天竜川以西に分布する更新統（小林, 1964 の浜松層）を天竜川以東に分布する下一中部更新統に 対比し，両者をまとめて小笠層群と再定義した。この層群は
Mikatagahara Formation

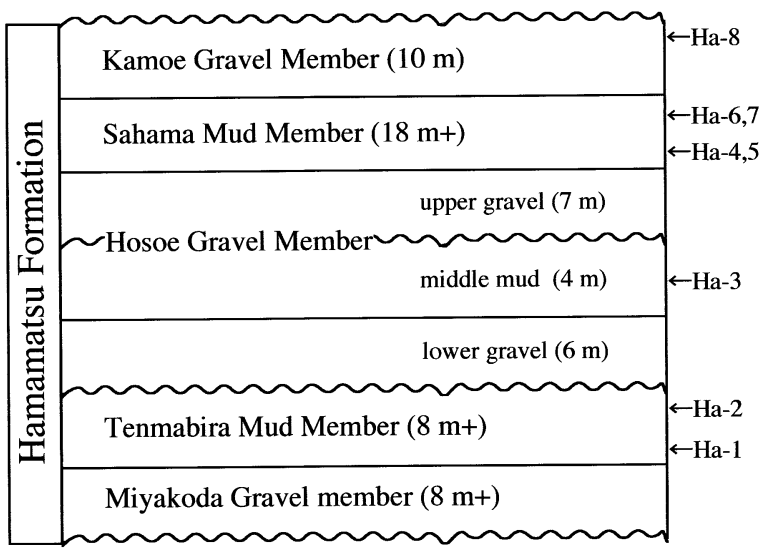

Fig.2. Stratigraphy of the Middle Pleistocene Hamamatsu Formation. Numerals in parentheses show the maximum thickness of each member. Ha-1 to Ha-8 mean key volcanic ash layers. After Sugiyama (1991).

6 つの層, すなわち, 下位より都田礫層, 矢満平泥層, 細江 碟層, 佐浜泥層, 志都呂砂層, 鴨江碟層からなるとした. 杉 山（1991）は浜名湖東岸地域に分布する中部更新統の名称に ついては，小林（1964）の浜松層を適用し，区分に関して は，志都呂砂層を佐浜泥層に含めたこと以外，基本的に武藤 （1987）の定義に従つた. 天満平と佐浜の 2 つの泥層は海成 層で, 都田, 細江, 鴨江の各碩層は河成層であるとし, 新た に, 細江碟層中に, 海成泥層 (中部泥層; Fig.2) が場所によ り挟在することを認め, 浜松層中には 3 層準に海成泥層が挟 在すると報告した，本研究対象である佐浜泥層はこれらの海 成泥層のうち, 最上位層にあたる. 浜松層中の命名されてい る各㗂層と泥層は, 杉山（1991）ではBed（単層）として 定義されているが, 入月ほか (2003a) と同様に, 本論文で は以後, 部層として扱うこととする (Fig.2).

浜松層には 8 枚の火山灰鍵層（Ha-1～Ha-8）が認められ (杉山, 1991), このうち, 佐浜泥部層中には 4 枚の火山灰鍵 層（Ha-4, 5, 6, 7) が挟在する. 佐浜泥部層の下位にある細 江碩部層の中部泥層中に挟在する Ha-3 火山灰層は, 大磯丘 陵の早田層に挟在するべージュタフと一致し, 佐浜泥部層中 の Ha-6, 7 火山灰層のペアは, 有度丘陵の Ng-2 火山灰層に 対比できるとして, 佐浜泥部層は酸素同位体ステージ 7 後半 の堆積物であると推定されている（杉山，1991）.しかしな がら, 本調査地域で広域に追跡できる $\mathrm{Ha}-4$ 火山灰層（中～ 粗粒砂サイズガラス質火山灰), Ha-5 火山灰層（細〜粗粒砂 サイズの結晶質火山灰）と広域対比に使われている Ha-6,7 火山灰層との上下関係は不明である（杉山，1991）。星・亀 井 (2003) は本研究と同じ地点で地層中の帯磁率を測定し, その変動パターンに基づいて地層の対比を行った.

佐浜泥部層から産出する化石に関しては, ナウマンゾウ化 石以外にも古くから多くの報告がなされている. その中でも 貝化石は豊富に産出し, Tegillarca granosa, Crassostrea gigas, Phacosoma japonicum, Theora fragilis, Raetel- 
lopus pulchellus などの内湾汽水性種が報告されている (Makiyama, 1924; 小林, 1942, 1964; Takai and Tsuchi, 1959; 土, 1960; 磯見・井上, 1972; 延原, 2003)。特に磯見・ 井上（1972）は貝化石群集の時間的・空間的な変遷を詳細に 報告している，また，土（1960）によると佐浜町付近から現 在台湾以南にしか生息していない貝化石 (Soletellina rostrata）が採集されている.このような貝化石の結果からは 当時の堆積環境は河口から静穏な閉鎖的内湾で, 現在の浜名 湖よりもわずかに大きく, 古水温は現在よりもわずかに高か つたと推定されている. 千地（1964）は本研究と同じ地点を 含む露頭から, 底生有孔虫化石のElphidium excavatum, Elphidium clavatum, Strebulus beccarii tepida (= Ammonia beccarii tepida) and Strebulus beccarii forma A (=Ammonia beccarii forma A) を報告し，これ
らから当時の古浜名湾は現在の浜名湖よりも外洋水の影響を 受ける汽水性内湾で, 貝化石の結果と同様に現在よりもわず かに古水温は高かったと結論した。 入月ほか（2003a）は模 式地の佐浜町において, 内湾沿岸性の貝形虫化石を報告して いる. 粉川（1964）や杉山（1991）は暖温帯性の植物遺体 や花粉化石を報告し, 吉川 (2000, 2002, 2003）は野ネズミ の食痕がついた多くの木の実化石などを発見し, 当時の河川 周辺の植生は落葉広葉樹林が主体であったと考察している.

\section{試料と採取地点の岩相}

佐浜泥部層は多くの貝化石を含んでいる.しかしながら, それらの款が溶脱している露頭が多く, 結果として保存の良 い貝化石が産出した浜松市の 4 地点, すなわち Site SW（庄 和町), Site $\mathrm{OH}$ (大人見町), Site $\mathrm{KH}$ (古人見町), Site $\mathrm{OK}$

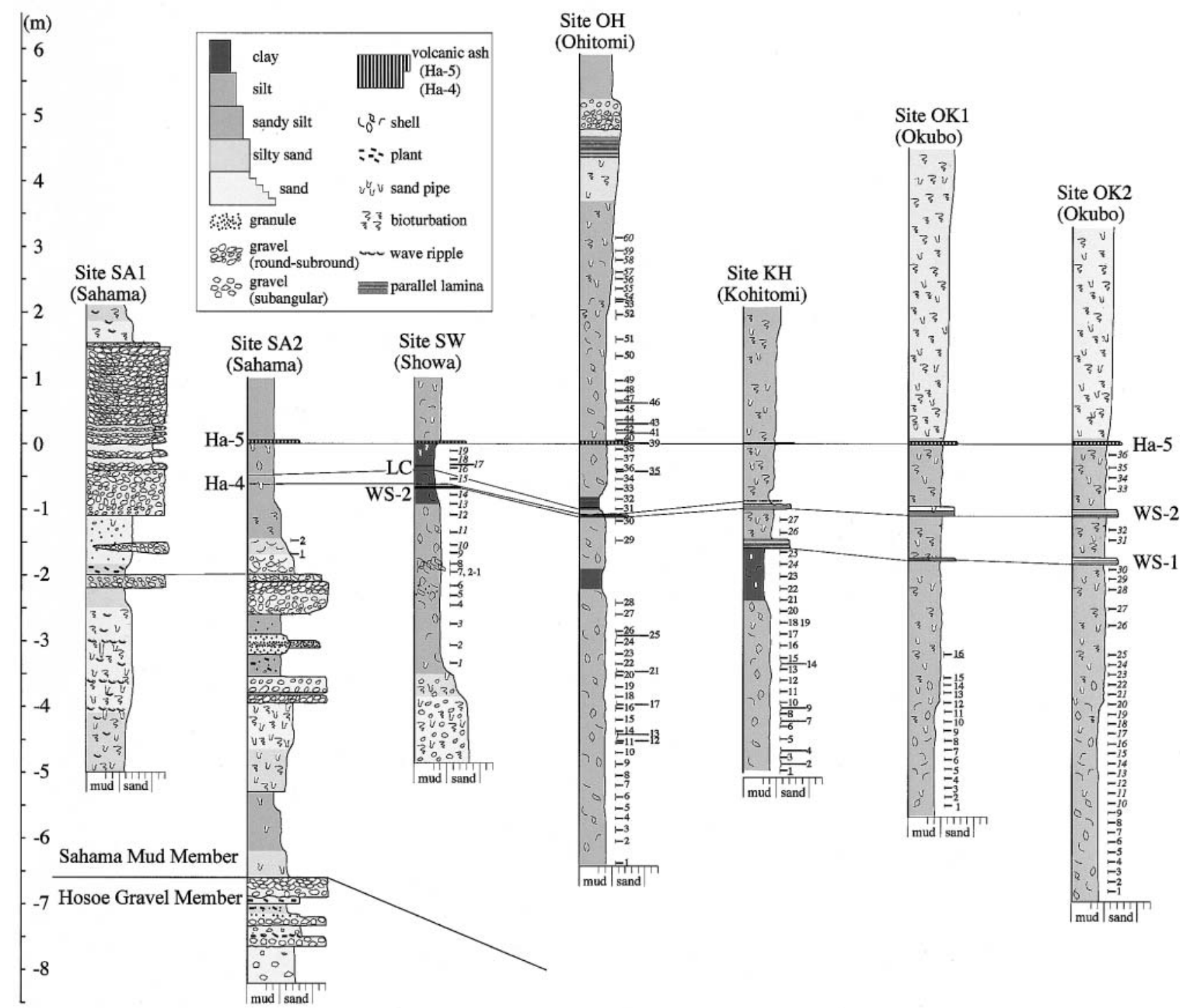

Fig.3. Columnar sections with sampling horizons. Ha-4 and Ha-5 show key volcanic ash layers of Sugiyama (1991). WS-1 and WS-2 mean wash over fine sand layers and LC shows a laminated clay layer. Italic numerals and numerals with underline mean samples only for CNS element analysis and only for fossil ostracode one, respectively. Other numerals show samples both for CNS element and ostracode analyses. 
（大久保町）において貝形虫化石と CNS 元素分析用の試料採 取を行った（Fig.1)。また，入月ほか（2003a）で報告され た佐浜町 (Site SA) における研究結果も本研究で引用し, 総合的に古環境の変遷を考察した，各地点の露頭柱状図を Fig.3 に示す.

\section{Site SA（佐浜町）}

この地点は研究地域の最も北東部にあり, Site SA1 と Site $\mathrm{SA} 2$ の 2 つの露頭がある。これらはそれぞれ，入月ほか （2003a）の東地区と西地区にあたる，ここについては，すで に堆積相と貝形虫化石群集の報告がなされている（入月ほか, 2003a）。それによると，浜松層は下位より 3 つの堆積相（I ～III）に区分され，堆積相 I は河口～湾奥三角州の頂置層, 堆積相 II は湾奥三角州の前置層, 底置層, 潮汐低地, 沿岸な ぞ，堆積相 III は内湾泥底と解釈されている，堆積相 I は細 江磉部層で, 堆積相 II と III が佐浜泥部層にあたる可能性が あるとされ，両者の境界面は佐浜町における海進面であると 考えられている. 貝形虫化石については, Site SA2 の堆積相 II から採取した泥質砂の 2 試料（SA-1，2）より, Spinileberis quadriaculeata, Aurila cymba なぞが産出し, 堆積 環境は湾沿岸砂泥底と推定された. Site SA2 には Ha-4, Ha-5 火山灰層とも確認できるが, Site SA1には認められない. な お，今回はここから CNS 元素分析用の試料を採取していな い.

\section{Site SW (庄和町)}

この地点は Site SA より約 $3.7 \mathrm{~km}$ 西方に位置している. 武藤（1987）の Loc. 25，杉山（1991）の Loc. 82，星・亀 井 (2003) の地点 SW に相当する. 露頭は全て佐浜泥部層 からなる. 露頭の最下部は, 層厚 $1.5 \mathrm{~m}$ で淘汰の悪い礫混じ りのシルト質砂からなり，生物擾乱が激しい。露頭の下〜中 部は層厚約 $4 \mathrm{~m}$ の青灰色塊状シルトで, 上方細粒化を示し, Dosinia, Raetellopus などの貝化石を豊富に含む．露頭上 部は風化が激しい，層厚約 $2 \sim 3 \mathrm{~cm}$ の平行葉理が認められ る細粒砂層（WS-2 層）が露頭の基底部から約 $4.2 \mathrm{~m}$ 上位に 挟在する. WS-2 層の直上には, 層厚 $1 \mathrm{~cm}$ 前後で断続的に 分布する Ha-4 火山灰層が認められる。層厚 $10 \mathrm{~cm}$ で平行葉 理の発達した粘土層（LC 層）が WS-2 層上限より約 25 〜 $35 \mathrm{~cm}$ 上位の層準に認められる。その上位に挟在する $\mathrm{Ha}-5$ 火山灰層は層厚 3〜 $4 \mathrm{~cm}$, 中粒砂サイズの火山灰からなり, 杉山（1991）によると，この層準の標高は約 12.5 m であ る.この地点では殼が保存された貝化石は Ha-5 火山灰層か ら約 $2.5 \sim 1.8 \mathrm{~m}$ 下位の層準にのみ認められ, $1.8 \mathrm{~m}$ 層準で は特に密集している.

試料は厚さ約 $5 \sim 10 \mathrm{~cm}$ ，間隔は約 $20 \mathrm{~cm}$ で，Ha-5 火山 灰層直下の層準までの泥質堆積物 19 試料（SW1-1～SW119）および試料 SW1-7 と同層準で，約 $20 \mathrm{~m}$ ほど南側に位 置する貝密集層から 1 試料（SW2-1）の合計 20 試料を採取 した.

\section{Site OH (大人見町)}

この地点は Site SA より約 $800 \mathrm{~m}$ 南東に位置し, 千地 （1964）の Loc. 708，杉山（1991）の Loc. 84, 星・亀井 （2003）の地点 $\mathrm{OH}$ と同一である. 露頭のほとんどが佐浜泥
部層からなり, 層厚 $10 \mathrm{~m}$ 程度の主として青灰色塊状シルト である．このシルトは上位に向け砂や黒雲母を多く含むよう になり，やや粗粒化する．露頭の基底部より約 $5.5 \mathrm{~m}$ 上位に は層厚 $3 \mathrm{~cm}$ のWS-2 層が挟在している（なお，試料採取後， 露頭下部が埋め立てられたため, WS-2 層は現在の露頭では 最下部に認められる). WS-2 層の直上には, 層厚約 $1 \mathrm{~cm} の$ Ha-4 火山灰層が断続的に認められる. Ha-4 火山灰層の約 $1.1 \mathrm{~m}$ 上位に Ha-5 火山灰層が挟在し，杉山（1991）による とこの層準は標高約 $11.5 \mathrm{~m}$ である. この火山灰層は白色で 層厚 4 $5 \mathrm{~cm}$, 中粒砂サイズで逆級化構造を示す. LC 層は 層厚約 $20 \mathrm{~cm}$ で, Ha-4 と Ha-5 火山灰層の間に発達してい る. 露頭最上部は下位より層厚 $1 \mathrm{~m}$ のシルト質砂から極細 粒砂へと上方粗粒化する砂層, 層厚 $20 \mathrm{~cm}$ の平行葉理砂層, 層厚 $30 \mathrm{~cm}$ の磻混じりのシルト質砂層, 層厚 $17 \mathrm{~cm}$ の砂を 少量含むシルト質砂層, 層厚 $60 \mathrm{~cm}$ の砂質泥層からなる. 保存状態の良い貝化石は露頭最下部から Ha-5 火山灰層の基 底部より上位 $2.15 \mathrm{~m}$ の層準まで散在しているのが認められ る. しかしながら, LC 層中と露頭最上部では貝化石が認め られなかった。

露頭の最下部から Ha-5 火山灰層の約 $3 \mathrm{~m}$ 上位の層準ま で, 試料の厚さ約 5 10 cm の泥質堆積物 60 個 (OH-1〜 OH-60) を採取した.

\section{Site KH（古人見町）}

この地点は Site SA より約 $1.7 \mathrm{~km}$ 南南西に位置し, 杉山 （1991）の Loc. 83，星・亀井（2003）の地点 KH に相当す る.ここでの佐浜泥部層は主に青灰色塊状シルト, 粘土, 砂 質シルトからなる。露頭下部は層厚 $2.5 \mathrm{~m}$ の塊状シル卜から なり, Dosinia, Dentalium, Raetellopus pulchellus など の保存良好な貝化石を含む. 露頭中部の $1 \mathrm{~m}$ はシルト質粘土 からなるが，貝化石の殼は溶脱している。露頭の基底部から $3.5 \sim 4.0 \mathrm{~m}$ 付近に 2 枚の細粒砂層（下位より WS-1 層と WS-2 層）が認められる. WS-1 層は層厚 $14 \mathrm{~cm}, \mathrm{WS}-2$ 層は 層厚 $7 \mathrm{~cm}$ で, 両層とも淘汰が良く, 平行葉理が顕著に認め られる. Ha-4 火山灰層は露頭の基底から約 $4 \mathrm{~m}$ 上位に挟在 する. Ha-5 火山灰層は層厚 $2 \mathrm{~cm}$ で, Ha-4 火山灰層の約 90 $\mathrm{cm}$ 上位に認められ，杉山（1991）によれば，この層準は標 高約 $13 \mathrm{~m}$ である. LC 層はこの地点では認められなかった. 露頭上部は生物擾乱が激しく, 風化したシルトからなる.

露頭最下部から WS-2 層直下の層準まで, 試料の厚さ約 5 $\sim 10 \mathrm{~cm}$ の泥質堆積物 27 個（KH-1 〜 KH-27）を採取した.

\section{Site OK（大久保町）}

この地点は Site SA より $2.7 \mathrm{~km}$ 南方に位置する広大な露 頭で, 武藤（1987）の Loc. 33 の近傍で, 星・亀井 (2003) の地点 TK2 と同一である. Site OK1 は Site OK2 から約 30 $\mathrm{m}$ 東に位置し, ぞちらも佐浜泥部層が露出している. Site OK2 の露頭下部は層厚約 $3 \mathrm{~m}$ で青灰色塊状シルトからなり, 生息姿勢を保ち，殼の保存状態の良い貝化石が認められる。 露頭中部は層厚 $4 \mathrm{~m}$ の厚さで, シルトから砂質シルトへ上 方粗粒化する. 貝化石は殼が溶脱し, 個体数も少ないが, 生 物擾乱や砂管が頻繁に認められる. WS-1 層は層厚 5 〜 10 $\mathrm{cm}$ で淘汰の良い細粒砂からなり, Site OK1 では露頭の基底 
Table 1. List of fossil ostracodes from the Sahama Mud Member. S, H (S) and BF mean number of species, species diversity and ostracode biofacies, respectively.

Au.c: Aurila cymba, Bi.b: Bicornucythere bisanensis, Bi.s: Bicornucythere sp., Ca.p: Callistocythere pumila, Co.i: Coquimba ishizakii, Cy.s: Cythere sp., Cn.m: Cytheropteron miurense, Cu.m: Cytherura miii, Da.s: Darwinula? sp., Lo.u: Loxoconcha uranouchiensis, Lo.s: Loxoconcha sp., Ne.d: Neomonoceratina delicata, Pi.f: Pistocythereis bradyformis, Pi.b: Pistocythere bradyi, Po.j: Pontocythere cf. japonica, Po.i: Pontocythere minuta, Po.m: Pontocythere miurensis, Po.1: Pontocythere sp. 1, Po.2: Pontocythere sp. 2, Ro.i: Robustaurila ishizakii, Sp.f: Spinileberis furuyaensis, Sp.q: Spinileberis quadriaculeata, Xe.h: Xestoleberis hanaii, Xe.s: Xestoleberis setouchiensis, Xe.p: Xestoleberis sp. Ge.s: Gen. et sp. indet.

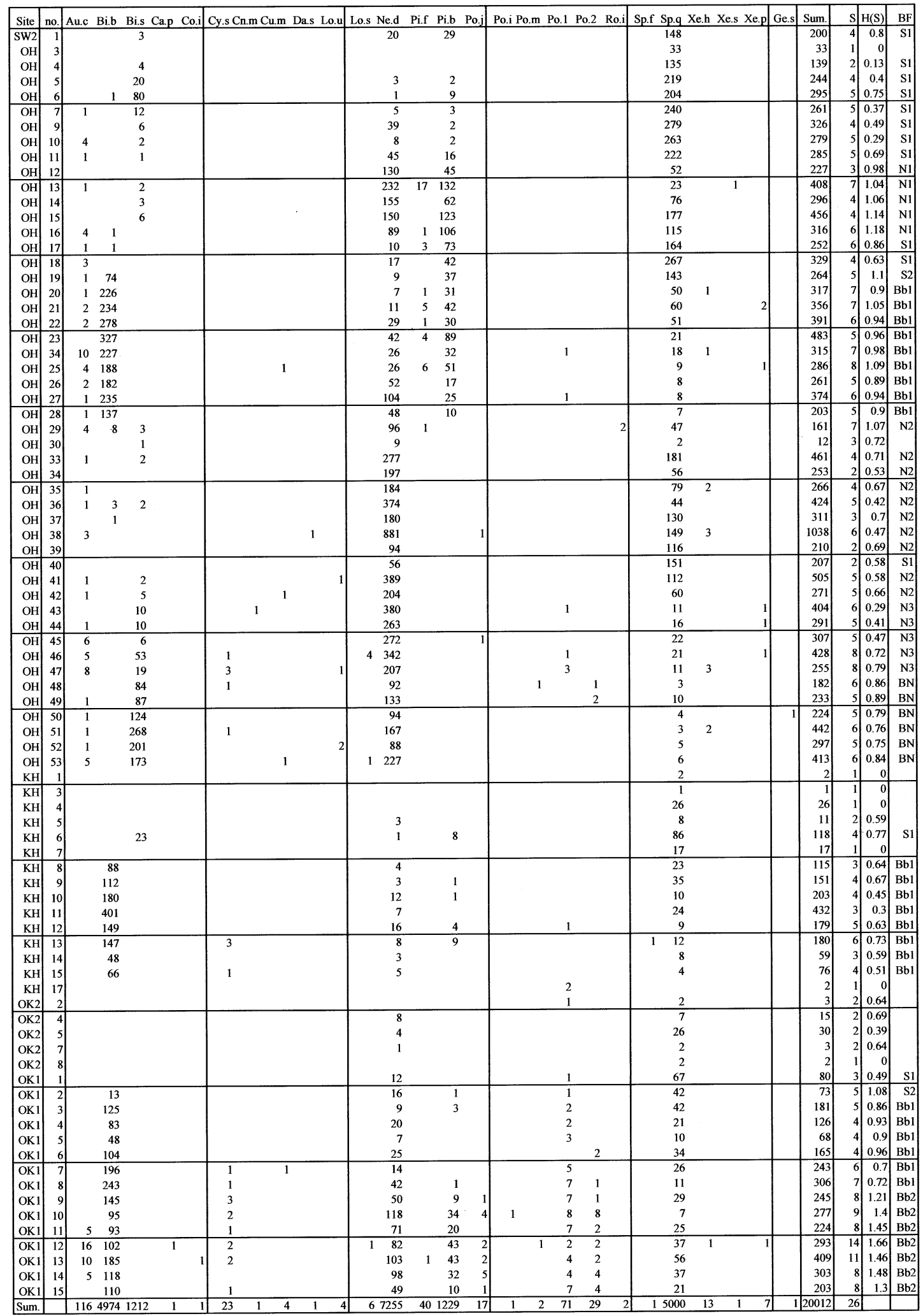


部より約 $4 \mathrm{~m}$ 上位, Site $\mathrm{OK} 2$ では約 $5 \mathrm{~m}$ 上位に挟在する. WS-2 層は層厚 $10 \sim 15 \mathrm{~cm}$ で, 淘汰の良い細粒砂からなり, 両地点とも WS-1 層の上限より約 $60 \mathrm{~cm}$ 上位に挟在する. これら 2 枚の砂層はそれぞれ下半部に平行葉理が発達し，海 側から陸側への砂粒のインブリケーション構造が顕微鏡観察 により認められる. 上半部は比較的塊状の構造を示す. Ha-4 火山灰層は認められない. Ha-5 火山灰層は WS-2 層の上限よ り両地点とも約 $1 \mathrm{~m}$ 前後上位に挟在するが，激しい生物擾 乱により認めにくい. LC 層はこの地点では認められなかつ た. 露頭上部は層厚 $4 \mathrm{~m}$ 以上のシルト質細粒砂からなり, 下位よりも生物擾乱が激しい.

Site OK1 では露頭下部から泥質堆積物 16 個（OK1-1 OK1-16), Site OK2 では露頭下部から Ha-5 火山灰層直下の 層準までの泥質堆積物 36 個（OK2-1 〜 OK2-36），合計 52 試料を採取した.

$$
\text { 方法 }
$$

\section{1. 貝形虫化石}

各地点から採取した試料のうち, 貝形虫化石の殼が溶脱し ていないと推測される試料 103 個を数日間 $60{ }^{\circ} \mathrm{C}$ に設定した 恒温乾燥器に入れ十分乾燥させ，乾燥重量 $80 \mathrm{~g}$ を目安に電子

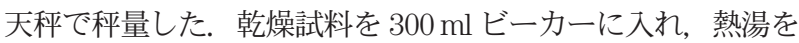
注ぎ約 1 時間煮沸した後, 200 メッシュ $(75 \mu \mathrm{m})$ の篩上で
水洗し, 再度乾燥させた. その後, 十分乾燥した試料に石油 ナフサを注ぎ, 1 時間放置後, ナフサを回収し，熱湯を注ぎ 約 2 時間煮沸させた。 その後, 同様に篩上で水洗し乾燥させ た. 細粒化した試料を, 含有する貝形虫化石の個数に応じて 分割器で分割し, 合弁殼, 片殼の区別なく約 200 個を目安に 分割試料から全ての殼を双眼実体顕微鏡下で拾いだした.

\section{CNS 元素分析}

測定に用いた 156 試料は約 $80^{\circ} \mathrm{C}$ 恒温乾燥器で十分乾燥 させた後, メノウ乳鉢で泥サイズになるまで砕き粉末にした, 再び乾燥させた各試料を銀製固体用コンテナーに入れ，粉末 試料の重量を $10 \mathrm{mg}$ を目安に電子天秤で正確に秤量した. その後，無機炭素を除去するために，1M 塩酸を適量注ぎ， $110{ }^{\circ} \mathrm{C}$ 設定したホットプレート上で 1 時間乾燥後, 再び $1 \mathrm{M}$ 塩酸を注ぎ 4 時間乾燥させ，それらを封入した。その 後，各試料をさらに錫製固体用コンテナーに入れ封入した. 測定には島根大学汽水域研究センター所有の FISON 社製 CHNS 元素分析計（EA1108）を使用した。標準試料には BBOT (2,5-bis- (5-tert-butyl-benzoxazol-2yl) -thiophen) を用い, 10 試料おきに標準試料を測定した.

\section{貝形虫化石分析結果}

1. 優占貝形虫種の生態と生物地理

貝形虫群集解析用に採取した 103 試料のうち, 84 試料か

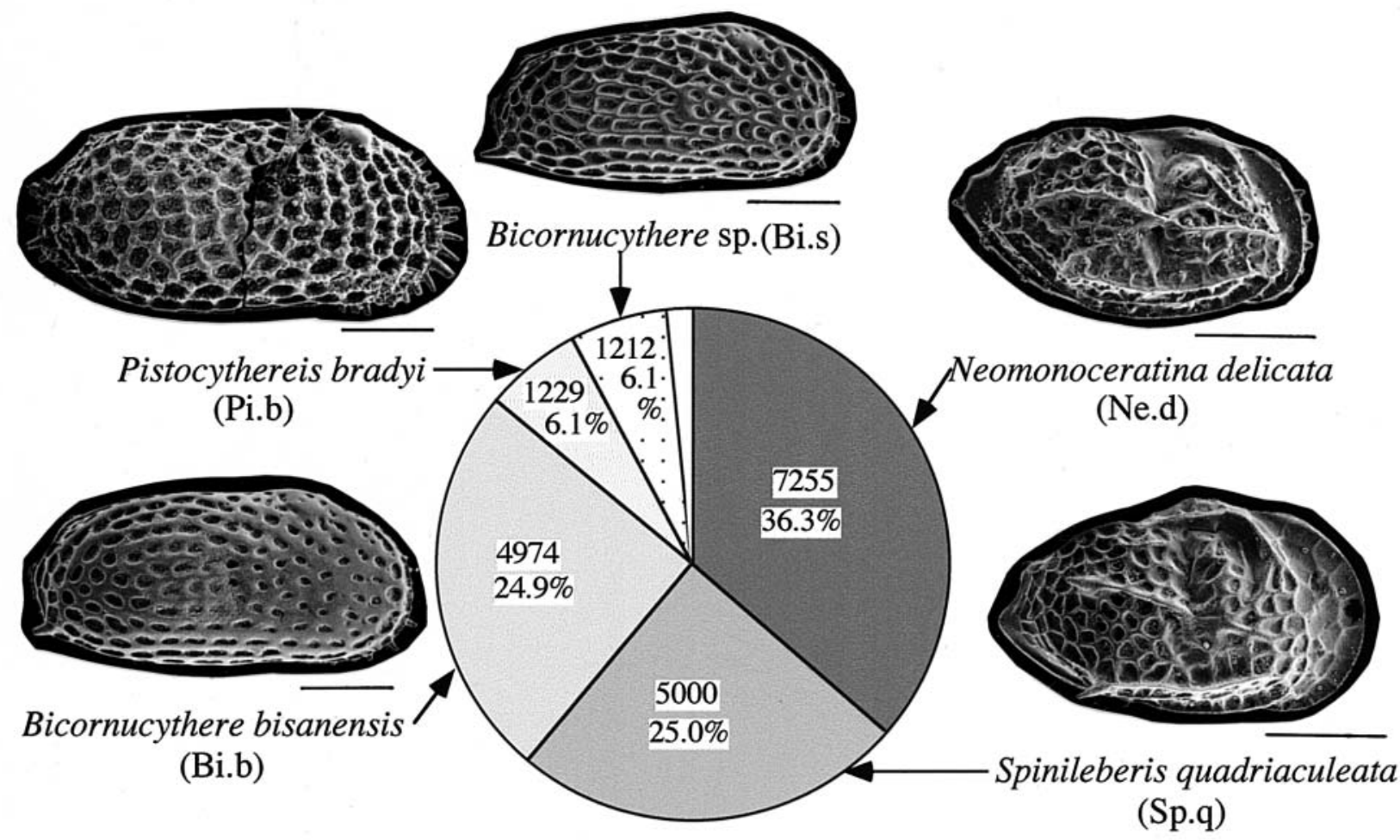

Number of total specimens $=20012$

Fig.4. Number of specimens, relative frequency (\%) and SEM micrographs of dominant species of fossil ostracodes from the Sahama Mud Member. Specimens of Bicornucythere bisanensis, Bicornucythere sp. and Pistocythereis bradyi are male right valves. Those of Neomonoceratina delicata and Spinileberis quadriaculeata are female right valves. Scale bars are $200 \mu \mathrm{m}$. 
ら 26 種の貝形虫化石が抽出された（Table 1)。優占種は 5 種で, Neomonoceratina delicata（総個数 7275 ; 相対頻度 $36.3 \%)$, Spinileberis quadriaculeata (5265; $25.0 \%)$, Bicornucythere bisanensis (5230; $24.9 \%)$, Pistocythereis bradyi (1284; $6.1 \%)$ およびBicornucythere sp. (1212；6.1％) である. これらで合計 98.3 \%に達する (Fig.4).これら 5 種についての生態や生物地理は以下のよ うである.

(1) Neomonoceratina delicata この種はこれまで Neomonoceratina microreticulate のシノニムであるとさ れてきたが (例えば, Hanai et al., 1977), Zhao and Whatley（1988）により N. microreticulateはN. delicataに比 べ, 網状装飾の網目（fossa）がより小さく密なことと, 強 く複雑な突起をもつことで区別できるとされた．この種は日 本において中〜後期更新世の地層からは多数の報告があるが (例えば, Ishizaki and Kato, 1976; Yajima, 1978, 1982; 中尾, 1993; 入月・細山, 2000 など), 日本列島周辺の現世堆積物 からは，保存状態の悪い片殼が大阪湾から報告されたにすぎ ず (Yasuhara and Irizuki, 2001), 生体は確認されていない. おそらく最終水期にこの種が生息できないほど海水温が低下 したことによって，九州以北では消滅したと考えられている (入月, 2002a). 現在は沖縄本島の羽地内海（田吹，私信）, 南シナ海（Zhao et al., 1985, Cai, 1988, 1993; Gou, 1990), マレー半島南東部の Jason Bay（Zhao and Whatley, 1989), マラッカ海峡（Whatley and Zhao, 1987）などの主に $20 \mathrm{~m}$ 以浅の海域に生息している. このように現在は暖流の影響を 強く受ける亜熱帯から熱帯の湾域に生息している.

（2）Spinileberis quadriaculeataこの種は沖緡本島を 含む日本列島各地の $5 \sim 8 \phi$ の底質で $20 \sim 30 \%$ の塩分を もち, 水深 $2 \sim 7 \mathrm{~m}$ の静穏で閉鎖的な内湾奥部泥底に優占 する種である (池谷・塩崎, 1993)。 また，中国でも $10 \sim 30$ 数 $\%$ の塩分をもつ沿岸部に生息している(例えば, Zhao and Wang, 1988).

(3) Bicornucythere bisanensis 本研究における $B$. bisanensis は Abe (1988) やAbe and Choe (1988) の Form Aにあたり, Okubo（1975）により瀬戸内海から記載 された模式標本と同じ形態である.この種は S. quadriaculeata よりも深く沖合の閉鎖的内湾の中央部泥底に優占す る種で (例えば, Ishizaki, 1971; 池谷・塩崎, 1993), 季節的 に貧酸素水塊が発達する島根・鳥取県の中海のような環境で も生息している (入月ほか, 2003b)。 日本では北海道サロマ 湖（伊藤, 1998a）から九州有明海（岩崎, 1992）まで広く生 息しており，韓国，中国沿岸域にも生息している（例えば， Abe, 1988)。このようにS. quadriaculeata が優占する場 所よりは沖合のやや深い内湾泥底に卓越する種である.

（4）Pistocythereis bradyi この種は北日本の青森湾 (Ishizaki, 1971) からマラッカ海峡（Whatley and Zhao, 1988）までの閉鎖的内湾泥底に生息し，韓国や中国沿岸の内 湾にも普遍的に生息している (Abe and Choe, 1988; Zhao and Wang, 1988).このように東アジアから東南アジアにか けて生息する広温性の内湾泥底種であるが, 現在非常に閉鎖
的な内湾である中海などには少ないことから（高安ほか， 1990; 入月ほか, 2003b), B. bisanensis に比べて貧酸素水塊 への適応が低いと推定される.

(5) Bicornucythere sp. 本研究における Bicornucythere sp.はAbe (1988) やAbe and Choe (1988) の Bicornucythere bisanensis の Form M に相当する可能性があ る. この種は現在, 大阪湾 (Yasuhara and Irizuki, 2001), 高知県浦八内湾 (Ishizaki, 1968), 有明海 (岩崎, 1992) に 見られ，本論文の筆頭著者は沖縄本島の中城湾の表層堆積物 からもこの種を確認している.このようにこの種は西南日本 の暖流影響下に生息し, 愛知県三河湾以東の太平洋側の内湾 域，日本海側全域の内湾域には生息していないようである. しかしながら, 化石としては本研究における報告以外にも中 部地方の中部更新統から産出している（例えば, 入月・細山, 2000; 入月ほか, 2002b). 有明海では水深 $3.7 \mathrm{~m}$ 付近に優占 し, 深度か増すにつれ減少し, かわりにB. bisanensisが増 加する傾向が報告されている（岩崎, 1992)，大阪湾ではこ のような傾向は認められない (Yasuhara and Irizuki, 2001). 浦ノ内湾ではB. bisanensis は生息していないようで, Bicornucythere sp.のみが水深 $2 \sim 16 \mathrm{~m}$ に生息し, $S$. quadriaculeata よりは湾口部側に多い（Ishizaki, 1968). このように, この種は現在暖温帯から带熱帯海域の湾沿岸部 で, B. bisanensis の生息場よりも浅く暖かい環境に多い種 である.

\section{2. 貝形虫化石相}

50 個以上の貝形虫化石を産出した 71 試料と, 入月ほか (2003a）における 2 試料（SA-1 とSA-2），およびいずれか の試料中に 3 個体以上含まれる 13 種を用いて, Q-mode ク ラスター分析を行った。 類似度は Horn（1966）の重複度指 数で, 各クラスターは UPGMA 法で連結した. 結果として 4 つの貝形虫化石相（Biofacies S, Bb, N, BN）が認められた (Fig.5, Table 2). 各地点における化石相の層位学的分布を Figs.6〜9 に示す.

(1) 化石相 S Spinileberis quadriaculeata の優占によっ て特徵づけられる.この化石相は $2 \sim 7 \mathrm{~m}$ 程度の水深の湾 奥泥底で，すべての化石相のうち，最も閉鎖的で塩分が低い 静穏な環境を示唆する. この化石相は 2 つの亜化石相（subbiofacies S1，S2）に区分される。亜化石相 S1 はほぼ S. quadriaculeata からなり, S2 は加えて B. bisanensisが付 随することから $\mathrm{S} 1$ より水深があり, 沖合の環境を示唆する. 亜化石相 S1 は Site SW の試料, Sites KH, OK の最下部層準 の試料, Site $\mathrm{OH}$ の最下部層準, 下部層準および Ha-5 火山 灰層準の試料から構成されている. 亜化石相 S2 は Site SA の試料，および Sites OH, OK での亜化石相 S1 と後述する 化石相 B との間の試料から構成される.

（2）化石相 N Neomonoceratina delicata の優占によっ て特徵づけられる.この化石相は暖流影響下の湾奥から湾中 央部泥底の環境を示唆する. 3 つの亜化石相 (subbiofacies N1，N2，N3）が区分できる. 亜化石相 N1 はN. delicataに 加えてP. bradyi やS. quadriaculeata が普遍的に付随す る. 亜化石相 $\mathrm{N} 2$ はS. quadriaculeata が付随するが, $P$. 


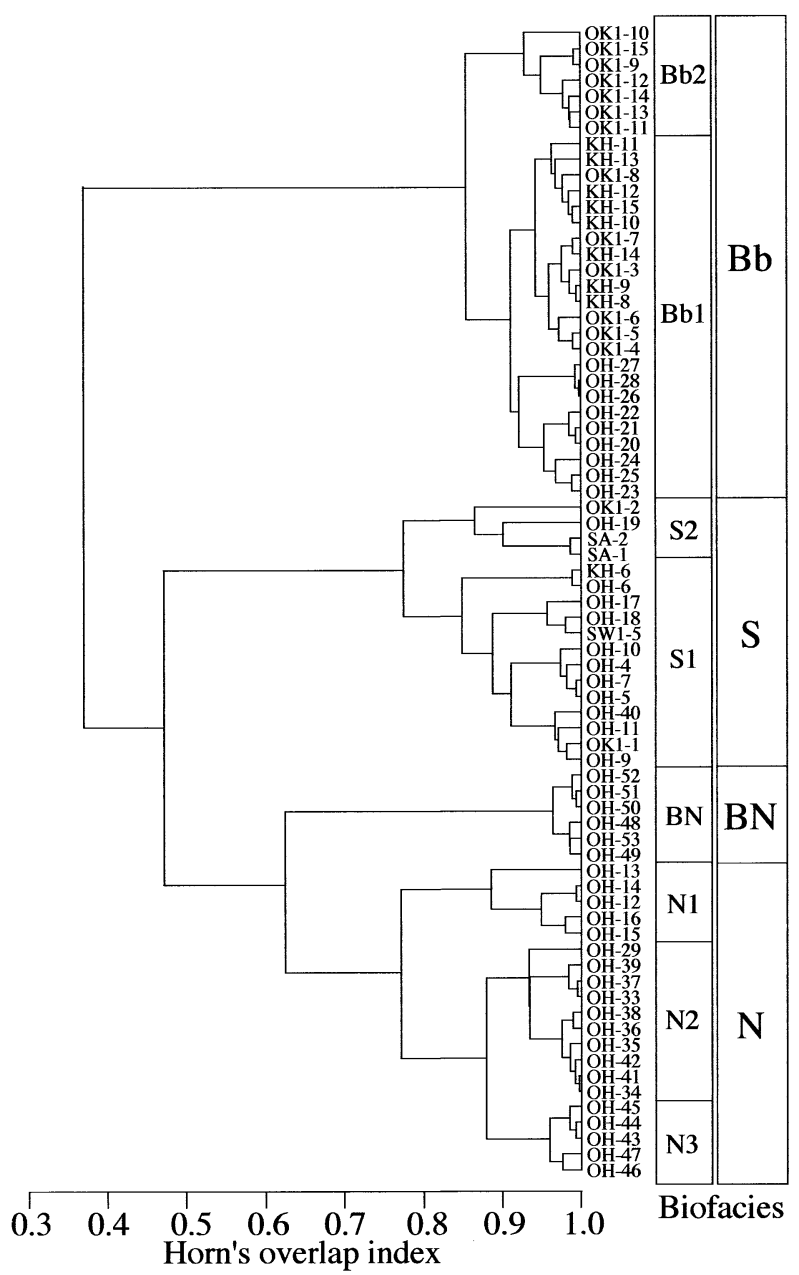

Fig.5. Dendrogram based on Q-mode cluster analysis. N, $\mathrm{BN}, \mathrm{S}$ and $\mathrm{Bb}$ show fossil ostracode biofacies. bradyi を欠いている. 亜化石相 N3 はほとんどN. delicata からなる.これらの違いは塩分や水深, 溶存酸素量の違いを 反映していると推定される。化石相 $\mathrm{N}$ はSite $\mathrm{OH}$ にの夕認 められ，下中部と中上部層準の試料から構成される.

(3) 化石相 $\mathbf{B b}$ Bicornucythere bisanensis の優占によつ て特徵づけられる.この化石相は閉鎖的内湾中央部泥底環境 を示唆し, 水深が他の化石相と比較して最も深く, 季節的に 貧〜無酸素水塊が広がる環境と推定される. Amphileberis nipponica, Kobayashiina donghaiensis, Krithe japon$i c a$ など水深 $15 \mathrm{~m}$ 以深の内湾で見られる貝形虫種が存在し ていないことから深くても水深 $10 \mathrm{~m}$ 前後と推定される. こ の化石相は 2 つの亜化石相（subbiofacies Bb1, Bb2）に区 分される. 亜化石相 Bb1 はほとんどB. bisanensis からな るが, 亜化石相 Bb2 は優占種であるB. bisanensis の他, N. delicata, P. bradyi, S. quadriaculeataを伴い, その 他の Pontocythere 属やCythere 属, Aurila 属などの湾沿 岸〜湾口砂底種, 葉上種も $7 \%$ 弱見られ, 種多様性 ( $\mathrm{H}$ (S) ) が $1.3 \sim 1.4$ と本研究の中では最も高いことから Bb2 のほうがより外洋からの影響を受けやすい, すなわち, 沿岸 あるいは湾口部に相対的に近い湾中央部泥底であると推定さ れる. 化石相 Bb は Sites OH, KH, OK で, 化石相 S の直上 の層準に分布し, Site OH では化石相 N によって覆われてい る. 亜化石相 Bb2 は調査地域最南部大久保町の Site OK1 に のみ認められる.

（4）化石相 BN Bicornucythere sp.とN. delicataの優占 によって特徴づけられる.いずれも暖流影響下の内湾種であ り，この化石相は暖流影響下の閉鎖的内湾沿岸部で化石相 S よりも暖かく, 外洋の影響を受けやすく, 化石相 $\mathrm{N}$ や化石 相 $\mathrm{Bb}$ よりも浅い環境を示唆する. 化石相 BN は Site $\mathrm{OH}$ の

Table 2. Relative abundance of each ostracode biofacies (BF) and inferred paleoenvironments. Abbreviations of ostracode species are the same as those in Fig.7.

\begin{tabular}{|c|c|c|c|c|c|c|c|c|c|c|}
\hline \multirow{2}{*}{$\mathrm{BF}$} & \multirow{2}{*}{ sub-BF } & \multirow{2}{*}{ site } & \multicolumn{6}{|c|}{ Ostracode species (\%) } & \multirow[b]{2}{*}{ environment } & \multirow[b]{2}{*}{ water depth } \\
\hline & & & Sp.qI & Bi.s & Ne.d & Pi. b & Bi. b & others & & \\
\hline \multirow{6}{*}{$S$} & \multirow{4}{*}{ S1 } & SW & 74.00 & 1.5 & 10 & 14.5 & 0 & 0 & \multirow{6}{*}{ brackish inner bay } & \multirow{4}{*}{ shallow $(2-7 m)$} \\
\hline & & $\mathrm{OH}$ & 81.93 & 4.78 & 7.031 & 5.69 & 0.08 & 0.50 & & \\
\hline & & KH & 72.88 & 19.49 & 0.85 & 6.78 & 0 & 0 & & \\
\hline & & OK1 & 83.75 & 0 & 15 & 0 & 0 & 1.25 & & \\
\hline & \multirow{2}{*}{ S2 } & $\mathrm{OH}$ & 54.17 & 0 & 3.41 & 14.02 & 28.03 & 0.38 & & \multirow{2}{*}{ shallow to deep } \\
\hline & & OK1 & 57.53 & 0 & 21.92 & 1.37 & 17.81 & 1.37 & & \\
\hline \multirow{3}{*}{$\mathbf{N}$} & N1 & \multirow{3}{*}{$\mathrm{OH}$} & 26.01 & 0.65 & 44.39 & 27.48 & 0.06 & 1.41 & \multirow{3}{*}{ inner to middle bay } & \multirow{3}{*}{ deep to shallow } \\
\hline & N2 & & 24.97| & 0.36 & 73.74 & 0 & 0.31 & 0.62 & & \\
\hline & N3 & & 4.81 & 5.82 & 86.88 & 0 & 0 & 2.49 & & \\
\hline \multirow{4}{*}{ B } & \multirow{3}{*}{$\mathrm{Bb} 1$} & KH & 8.96 & 0 & 4.16 & 1.08 & 85.38 & 0.43 & \multirow{4}{*}{ middle bay } & \multirow{4}{*}{$\operatorname{deep}($ ca.10m) } \\
\hline & & $\mathrm{OH}$ & 7.77 & 0 & 11.55 & 10.95 & 68.12 & 1.61 & & \\
\hline & & $\mathrm{OK} 1$ & 13.22 & 0 & 10.74 & 0.37 & 73.37 & 2.30 & & \\
\hline & $\mathrm{Bb} 2$ & OK1 & 10.85 & 0 & 29.22 & 9.77 & 43.40 & 6.76 & & \\
\hline $\mathrm{BN}$ & & $\mathrm{OH}$ & 1.73 & 52.32 & 44.72 & 0 & 0 & 1.23 & inner bay & shallow \\
\hline
\end{tabular}




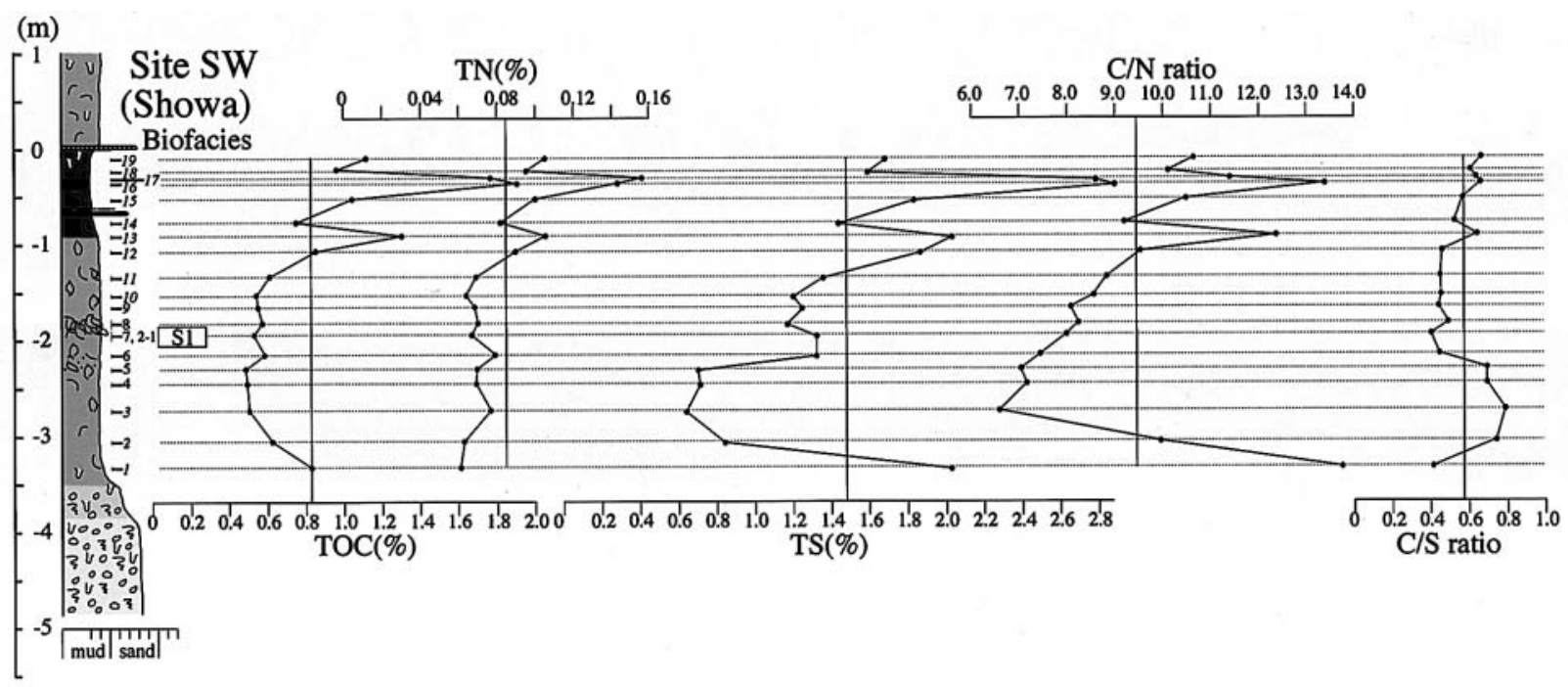

Fig.6. Columnar section, ostracode biofacies and vertical changes of TOC, TN and TS contents (\%), C/N and C/S ratios at Site SW (Showa-cho).

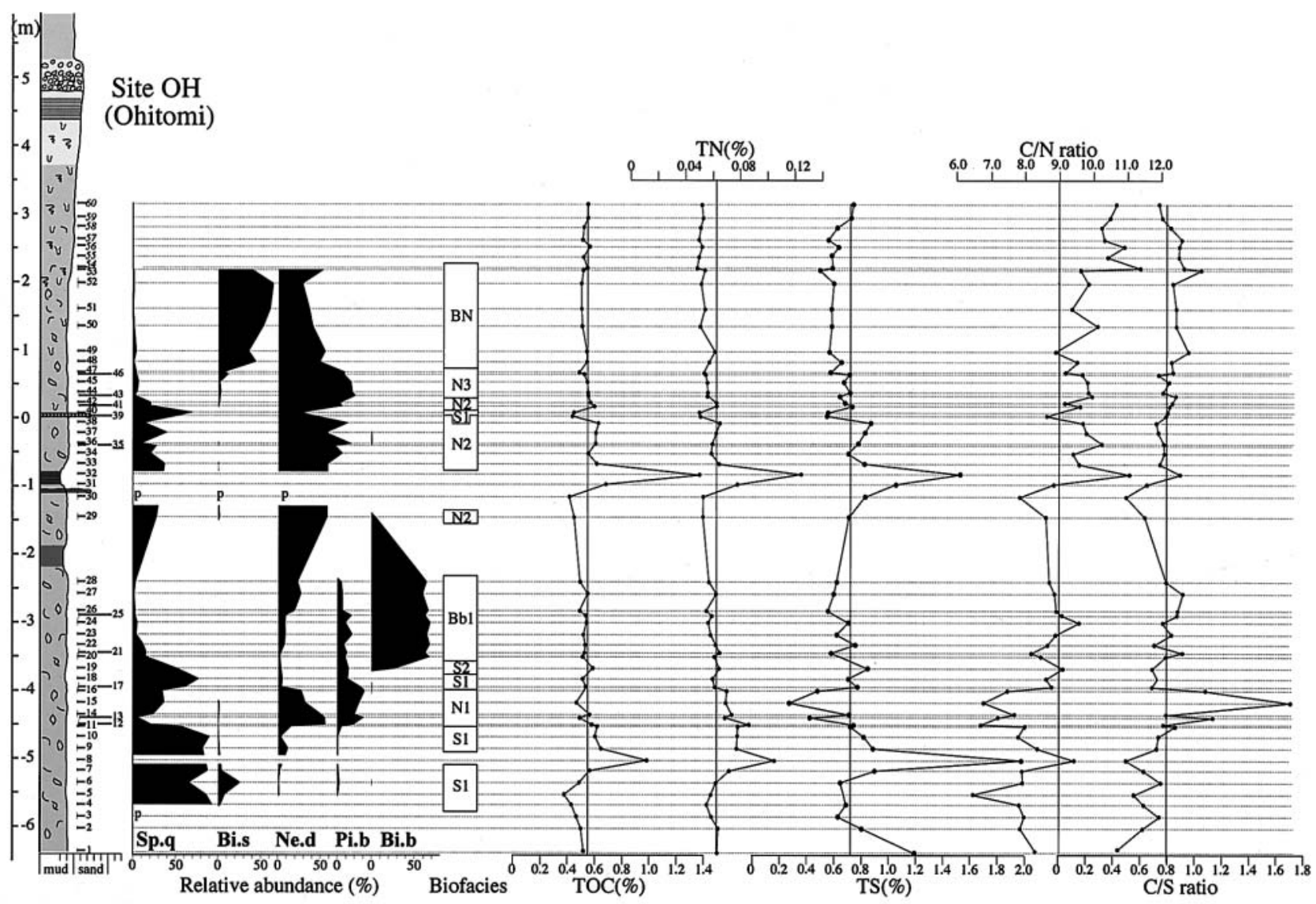

Fig.7. Columnar section, vertical changes of relative abundance (\%) of ostracodes, ostracode biofacies, TOC, TN and TS contents (\%), C/N and C/S ratios at Site OH (Ohitomi-cho). p shows the presence of ostracodes in samples containing less than 50 specimens. Sp.q: Spinileberis quadriaculeata, Bi.s: Bicornucythere sp., Ne.d: Neomonoceratina delicata, Pi.b: Pistocythereis bradyi, Bi.b: Bicornucythere bisanensis 


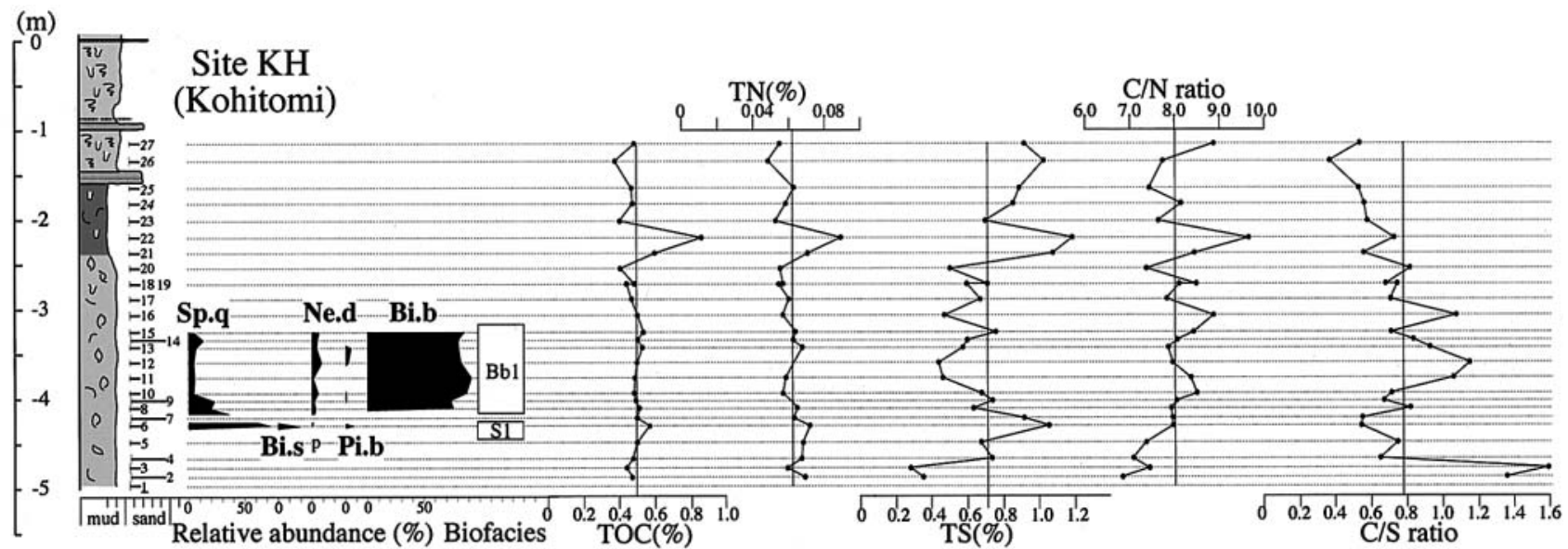

Fig.8. Columnar section, vertical changes of relative abundance (\%) of ostracodes, ostracode biofacies, TOC, TN and TS contents (\%), C/N and C/S ratios at Site KH (Kohitomi-cho). Abbreviations are the same as those in Fig.7.

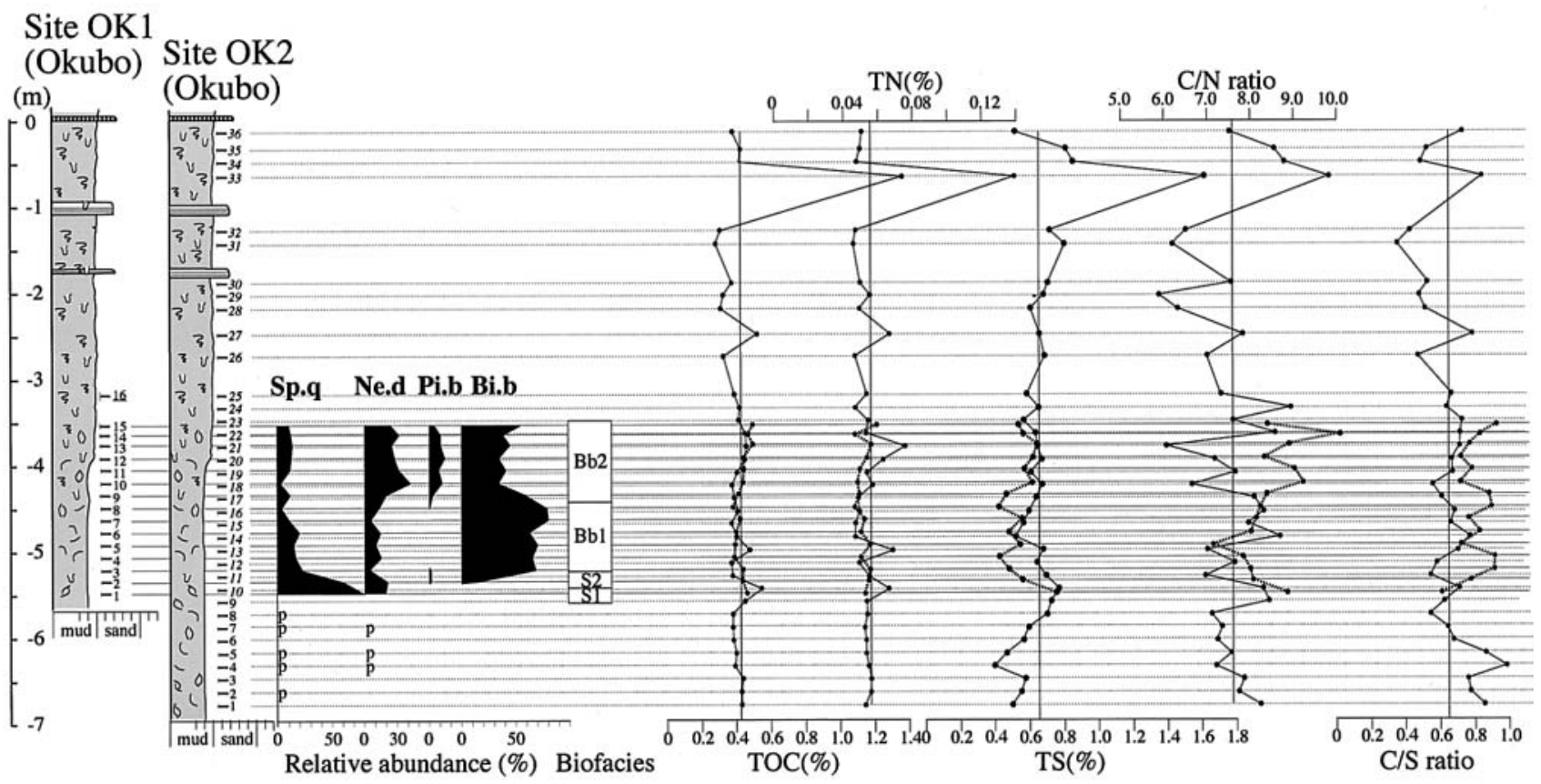

Fig.9. Columnar sections, vertical changes of relative abundance (\%) of ostracodes, ostracode biofacies, TOC, TN and TS contents (\%), C/N and C/S ratios at Site OK (Okubo-cho). Abbreviations are the same as those in Fig.7.

最上部層準の試料のみから構成される.

\section{CNS 元素分析の結果}

各地点における TOC, TN, TS 含有率, および C/N 比, C/S 比の垂直変化を Figs. 6 〜 9 に示す.

\section{Site SW}

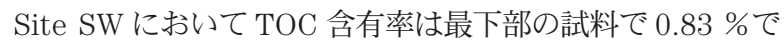
あるが, 上位へ向け減少し $0.5 \%$ 前後となる. 再び試料 SW1-12 から増加し, 試料 SW1-13 と LC 層から採取した試 料 SW1-16 にピークがあり，前者は $1.3 \%$ ，後者はそれぞ れ 1.9 \%に達する. TN 含有率も TOC 含有率と同調した変
動を示すが, TOC 含有率がやや高い下部の 2 試料（SW1-1 とSW1-2）では低い值（約 $0.06 \%$ ） となっている. TS 含有 率は最下部の試料 SW1-1 で $2.0 \%$ と高い值を示し, その上 位の試料 SW1-2 で急激に減少し, 試料 SW 1-5 まで 0.64 $0.84 \%$ で安定した低い值となる. 再び試料 SW1-6 で急激に 増加し, 1.3 \%前後となり, 若干その上位で減少するが, 他 の含有率と同様に試料 SW1-13 と LC 層から採取した試料 SW1-16 にピークがあり，前者では $2.0 \%$ ，後者でそれぞれ 2.9 \% となる. C/N 比は最下部の試料 SW1-1 で 13.8 という 高い值を示すが, 試料 SW-3 の 6.57 まで急減し, 試料 SW113 とW1-16 にそれぞれ 12.4 と 13.4 の 2 つのピークが認め 
られる他は，上位へ向けほぼ直線状に増加する. C/S 比の変 化は, 最下部で 0.41 と低く, 試料 SW1-2 から SW1-5 で 0.7 〜 0.8 となり，その上位で再び低くなり, $0.4 \sim 0.5$ を推移 し, 上位へ向け若干高くなる傾向を示す。

\section{Site OH}

Site $\mathrm{OH}$ では TOC 含有率も TN 含有率もほぼ同じような 変動を示し, 貝形虫化石が産出しなかった下部層準の試料 OH-8 でそれぞれ 0.98 \%と $0.1 \%$ \%ピーク，LC 層から採取 した試料 OH-32 でそれぞれ, $1.4 \%$ と $0.12 \%$ のピークを示 すが, 全体を通じて TOC 含有率は $0.5 \sim 0.6 \%$ 前後, TN 含 有率は $0.05 \sim 0.06 \%$ で安定している. わずかに下部から中 部に関して減少傾向が認められる. TS 含有率はいくつか増 減が認められる. 下部では試料 OH-8 で $2.0 \%$ のピークを伴 い, 全体的に $0.6 \sim 0.8 \%$ 前後であるが, 試料 $\mathrm{OH}-15$ 周辺 で $0.2 \sim 0.4 \%$ の低いピークが存在する. その上位では再び $0.8 \%$ 前後に戻り, 若干の増減を繰り返しながら上位へ向け 減少傾向を示す．LC 層から得られた試料 OH-32 で $1.5 \%$ の 大きなピークを示し, 再び減少し, 最上部まで 0.6 \% 前後の 安定した值を示す. $\mathrm{C} / \mathrm{N}$ 比は地層の下部, 中部, 上部で異な る. 下部では試料 $\mathrm{OH}-8$ で 9.4 の極大值を持つが，おおよそ $7 \sim 8$ 前後の值で, 試料 SW-17 においてやや増加する. 中 部では 9 前後で安定している. 試料 SW-32 で極大を示し, 上部では $9 \sim 10$ 前後となる. C/S 比に関しては, 試料 $\mathrm{OH}-$ 13, 15, 16 で 1 以上の高い值を示すが，他はおおよそ 1 以下 の低い值を示す。試料 OH-27 から Ha-4 火山灰層の層準に かけて若干減少傾向が認められるが, その上位では 0.8 前後 で安定している.

\section{Site KH}

Site KH では TOC・TN 含有率とも安定した值をとり, 前者は $0.4 \sim 0.5 \%$ 前後, 後者は $0.05 \sim 0.06 \%$ 前後で, $上$ 位に向け若干減少する傾向が見られる。 ただし, 試料 KH-21 および KH-22 では TOC 含有率がそれぞれ $0.6 \%, 0.86 \%$, TN 含有率がそれぞれ $0.07 \%, 0.09 \%$ という高い值を示す. TS 含有率は最下部（試料 KH-2 および KH-3）では $0.3 \%$ 前 後と低い值をとるが, 急激に増加し, 試料 KH-6 で $1.1 \%$ をを 示すピークが存在する. その上位で再び減少し, 試料 KH-12 で $0.44 \%$ となり, 再び増加に転じ, 増減を繰り返す，上部 では増加し, 特に試料 KH-21, KH-22 で 1.0 \%を越える高い 值を示す. $\mathrm{C} / \mathrm{N}$ 比は最下部の試料 $\mathrm{KH}-2$ で最も低く, 6.9 の值 を示す。 上位へ向け増加し，試料 KH-22 で極大值 9.65 とな るが, おおよそ 8 前後で増減を繰り返す. C/S 比については, 最下部で 1.5 前後の高い值を示し, 急激に減少し, 試料 KH11 で再び増加し，その上位では増減を繰り返しながら上位 へ向け再び減少する傾向を示す.

\section{Site OK}

Site OK1 では下部層準, Site OK2 では下部から Ha-5 火山 灰層までの層準で変動が認められる. TOC・TN 含有率はお 互い類似した変動を示し, 上部の試料 OK2-33 で認められる 大きなピーク（TOC: $1.4 \%$, TN: 0.14 \%) を除いて若干変動 はあるものの, 前者は $0.4 \%$ 前後, 後者は $0.05 \%$ 程度で安 定している. TS 含有率は下部の試料 OK2-4 付近の層準で低
い值を示し (0.4 \%)，その上位で上昇し, Sites OK1, OK2 ともに試料 OK1-1 や OK2-10 の層準でやや高い値（約 $0.8 \%$ ）を示す. 再び減少し, $0.5 \sim 0.6 \%$ 前後で安定する が, 試料 OK2-33 の層準でのみ $1.6 \%$ という高いピークを示 す. C/N 比は中部層準に極大があるが, Site OK2 では下部か ら上部の試料 OK2-32 向け, 増減を繰り返しながら減少し ている. 試料 OK2-33 で極大值 9.8 となり, この層準付近で は 8〜9 前後となる. Site OK1 では試料 OK1-14 に極大值 10.0 が存在するが, 7 〜 の間を変動している. C/S 比に関 しては最下部で相対的に高い值を示すが，その上位では小幅 な変動を繰り返し，上位へ向け若干の減少傾向が認められ る.

\section{考察 \\ 1. 貝形虫化石相と古環境}

貝形虫化石に関しては, 地層の垂直変化に伴う特徵的な種 の初産出と頻度の極大に関する典型的な順序が Site $\mathrm{OH}$ で認 められる。すなおち, S. quadriaculeata $\rightarrow$ Bicornucythere sp. $\rightarrow N$. delicata $\rightarrow P$. bradyi $\rightarrow B$. bisanensis $\rightarrow N$. delicata $\rightarrow$ Bicornucythere sp.となっており, B. bisanensis の多産層準（亜化石相 $\mathrm{Bb} 1$ ) を挟んで, 上下で N. delicata と Bicornucythere sp の産出順序と頻度の極大 が対称的になっている. また, 貝形虫化石相の基本的な垂直 変化は $\mathrm{S}$ (水深 $2 \sim 7 \mathrm{~m}$ 程度の閉鎖的湾奥泥底) $\rightarrow \mathrm{N}$ (暖流 の影響を強く受ける亜熱帯から熱帯の湾奥〜中央部泥底） $\rightarrow$ $\mathrm{S}$ (水深 $2 \sim 7 \mathrm{~m}$ 程度の閉鎖的湾奥泥底) $\rightarrow \mathrm{Bb}$ (水深 $10 \mathrm{~m}$ 程度の開鎖的内湾中央部泥底） $\rightarrow \mathrm{N}$ (暖流の影響を強く受け る亜熱帯から熱帯の湾奥から中央部泥底）－BN（暖流影響 下の閉鎖的湾奥沿岸部) である. Spinileberis quadriaculeata が海進初期に内湾へ侵入する例は過去の日本におけ る更新世〜完新世の内湾堆積物の研究に共通して認められる (Ishizaki and Kato, 1976; Frydl, 1982 など). また, Bicornucythere 属に注目すると, 縄文海進初期（約 8,000 cal yBP 以前）にBicornucythere sp.がまず出現し，その後， 海水準上昇と共にB. bisanensis が優占し, 縄文海進のピー クを過ぎると再びBicornucythere sp.が優占し始める傾向 が西日本の神戸沖大阪湾 (Irizuki et al., 2001), 大阪平野 (Yasuhara et al.. 2002a, 2002b; Masuda et al., 2003 など), 熊本平野 (岩崎, 1992) などの研究で認められている. 本研 究においてもこのようなパターンが認められることから, 貝 形虫化石相は相対的海水準変動による古水深の変化に最も左 右されているといえる. ただし, 東日本の後水期の堆積物か ら Bicornucythere sp.は全く産出せず, S. quadriaculeata の卓越の後, B. bisanensis が優占するようになる (例え ば, 入月ほか, 1998)。また, 前述したように, N. delicata は最終水期に九州以北の日本沿岸から姿を消したので, 西日 本における完新世の内湾貝形虫種の変遷パターンと今回のそ れとの違いは N. delicataの産出頻度の極大層準（すなわ ち, 化石相 N）が前者では認められないのに対し，後者では B. bisanensis とBicornucythere sp.の極大層準の間に 2 層準挟在することである. 


\section{2. 現在の浜名湖に見られる貝形虫群集との違い}

現在の浜名湖における貝形虫群集は 1971 年 8 月, 1974 年 11 月および 1975 年 9 月に採取された試料に基づく Ikeya and Hanai（1982）および 1996 年に 10 月に採取された試 料による伊藤（1998b）がある．これらのデー夕を総合する と, 現在の浜名湖中央部や支湖である庄内湖の泥底で優占す る種はS. quadriaculeata とCytheromorpha acupunctata の 2 種で, 佐浜泥部層から産出した優占種 5 種のうち, S. quadriaculeata 以外の 4 種は全く生息していないこと になる．また，池谷ほか（1990）では内湾指標種として日本 各地に生息するBicornucythere bisanensis が現在の浜名 湖では産出しないことが大きな特徴であると述べている．伊 藤 (1998b) の研究でも B. bisanensis の欠如が浜名湖の地 域的な特徵であると述べているが，本論文の筆頭著者は 1998 年, 浜名湖の湾口部付近から B. bisanensis の生体を 多数確認した. すなわち, 最近になってようやくB. bisanensisが浜名湖へ侵入したことになるが, 依然として, 現 在の浜名湖の中央部泥底を占める種は S. quadriaculeata である. ただし, Pistocythereis 属貝形虫は淡水化する前の 浜名湖には多く生息していたようである（池谷ほか, 1990).

このように現在の浜名湖は本格的に海水が流入した 1498 年からまだ 500 年余りしか経っていないために, 佐浜泥部層 堆積初期に見られた群集 (S. quadriaculeata を主体とする 亜化石相 S1）が湖中央部泥底を占めていることになる.

\section{TOC, TN, TS 含有率, C/N 比, C/S 比と古環境}

TOC 含有率は, 古浜名湾内の生物による有機物の生产量, 湾外から供給された有機物の負荷量, それらの分解量, 堆積 物の堆積速度に関連して変化する. $\mathrm{C} / \mathrm{N}$ 比は有機物の起源を 反映する (中井ほか, 1982; 三瓶ほか, 1997)。C/N 比は海洋 プランクトン起源では 6 前後, 陸上の高等植物起源では 15 以上になるとされている(例えば, 三瓶ほか, 1997).

現在の浜名湖では $\mathrm{C} / \mathrm{N}$ 比が $12 \sim 14$ 前後と比較的高い場 所は北部の猪鼻湖，西部の松見が浦，引佐細江などの河口部 で, 主湖や庄内湖の中央部では 8 前後の低い值を示し, 海洋 プランクトン起源の有機物が濃集している（倉門ほか, 1998)。今回もほとんどの試料で $\mathrm{C} / \mathrm{N}$ 比が 10 以下の值を示 しており, 全体的には海洋プランクトン起源の有機物から構 成されていると言える。しかしながら, Site SW の露頭最下 部と上部および Site $\mathrm{OH}$ の露頭上部から得られた試料は C/N 比が 10 以上の若干高い值を示すことから，これらについて は，陸域からの有機物が供給されるような相対的に河口域に 近い場所であったと推定される. TN 含有率には有機窒素の 他に無機態の窒素も含まれており，それらは粘土鉱物中に存 在していることが知られている (三瓶ほか, 1997)。本研究で はほとんどの試料で TOC 含有率が $1 \%$ より低く, C/N 比に は無機態の窒素の影響が表れる可能性がある. しかしながら, $\mathrm{C} / \mathrm{N}$ 比が 6 よりも低い值をとる試料は Site OK の試料 OK229 を除いて存在しなかった.

イオウは堆積物中において黄鉄釷の形態で保存される. 黄 鉄釷の形成には水中の硫酸イオン, 有機物, 硫酸還元バクテ リア，鉄イオンが必要である，イオウ濃度は火山性のものを
除き, 水塊中に含まれる硫酸イオンの有無, 堆積速度および 鉄イオン濃度に左右される。また，三瓶ほか（1997）や Sampei et al. (1997) によると, C/S 比は汽水〜海水成の場 合には，酸化還元度もある程度議論することが可能であり, 3 前後は通常の酸化的な海底泥質堆積物で, 1 前後は底層水が 貧酸素となりやすい汽水から内湾堆積物であるとされてい る. 本研究では Site $\mathrm{OH}$ の露頭下中部, Site $\mathrm{KH}$ の露頭下部 を除いて全て 1 前後あるいはそれ以下であることから, 季節 的に底層に貧〜無酸素水塊が広がる極めて閉鎖的な環境が示 唆される. 特に Site SW はTS 含有率に関して他と比べて全 体的に高い值を示し, $\mathrm{C} / \mathrm{S}$ 比に関してはより低い值となって いる. 現在の浜名湖では南部から北部, すなわち湖口から離 れるにつれて C/S 比が高くなっており（倉門ほか，1998）, Site SW が最も外洋からの影響を受けにくい静穏で閉鎖的な 内湾泥底であったことを示唆している.

\section{4. 各地点間の対比と古環境の時間空間的変化}

各地点間を対比する同時間面として有効な地層は, 佐浜泥 部層中部に挟在するWS-1, WS-2 層の砂層とそれらより上位 の Ha-4, Ha-5 火山灰層である. WS-1 層の上限から WS-2 層 の下限までの層厚は, これらが露出している Site KHでは $45 \mathrm{~cm}$, Site OK では $53 \mathrm{~cm}$ である. 圧密の影響が同じと仮 定すれば, Site KH と Site OK との間に関しては, 少なくと もこの時期の堆積速度は約 1.2 倍の差があることになる。 こ れは Site OK は最も南側に位置し, 湾口部の砂州形成部に相 対的に近いことを反映しているかもしれない，なお，これら の砂層は海側から陸側への古流向を示し, 古浜名湾内で比較 的広範囲に認められ, また, 上下は内湾成の泥質堆積物に挟 まれていることからウォッシュオーバーサンドであり, 大規 模なストームあるいは津波により形成されたと推定される. WS-2 層の上限から Ha-5 火山灰層の下限までの正確な厚さ はSite SW では $62 \mathrm{~cm}$, Site OH では $112 \mathrm{~cm}$, Site KH では $92 \mathrm{~cm}$, Site OK では $98 \mathrm{~cm}$ であり, この区間では Site SW で最も堆積速度が遅く, ついで Site KHで, Site OH で最も 速い.この区間での Site KH と Site OK に関しては, 約 1.1 倍の差となり, 両地点間での堆積速度の差が縮小している. 下部層準に関しては, 残念ながらこのような鍵層が挟在して いないため, 各地点間の同時間面を正確に設定することがで きない。 また，上記のように各地点でそれぞれ区間ごとに異 なる堆積速度の変化を示すことから, 上部層準で推定された 堆積速度を下部層準に適用することもできない，そこで，各 地点の $\mathrm{C} / \mathrm{N}$ 比, $\mathrm{TS}$ 含有率および $\mathrm{C} / \mathrm{S}$ 比の変動パターン, 特 に TS 含有率の極大層準に着目し, 各地点間で共通した含有 率の濃集のピークに基づき対比を行った. ただし, 地点間で これらのピークに若干の時間差があるかもしれないというこ とは否定できない。各地点間における TS 含有率と貝形虫化 石相の対比を Fig.10 に示す. (1) (5) TS 含有率が極大に なる層準である.

以上のような各地点間の対比に基づくと, 古浜名湾の時間 的・空間的環境変遷は以下のように復元される.

（1）最下部〜層準 (1) Site OH での夕認められる。この区間 では貝形虫の亜化石相は $\mathrm{S} 1$ で, 水深 $2 \sim 7 \mathrm{~m}$ の汽水性の閉 


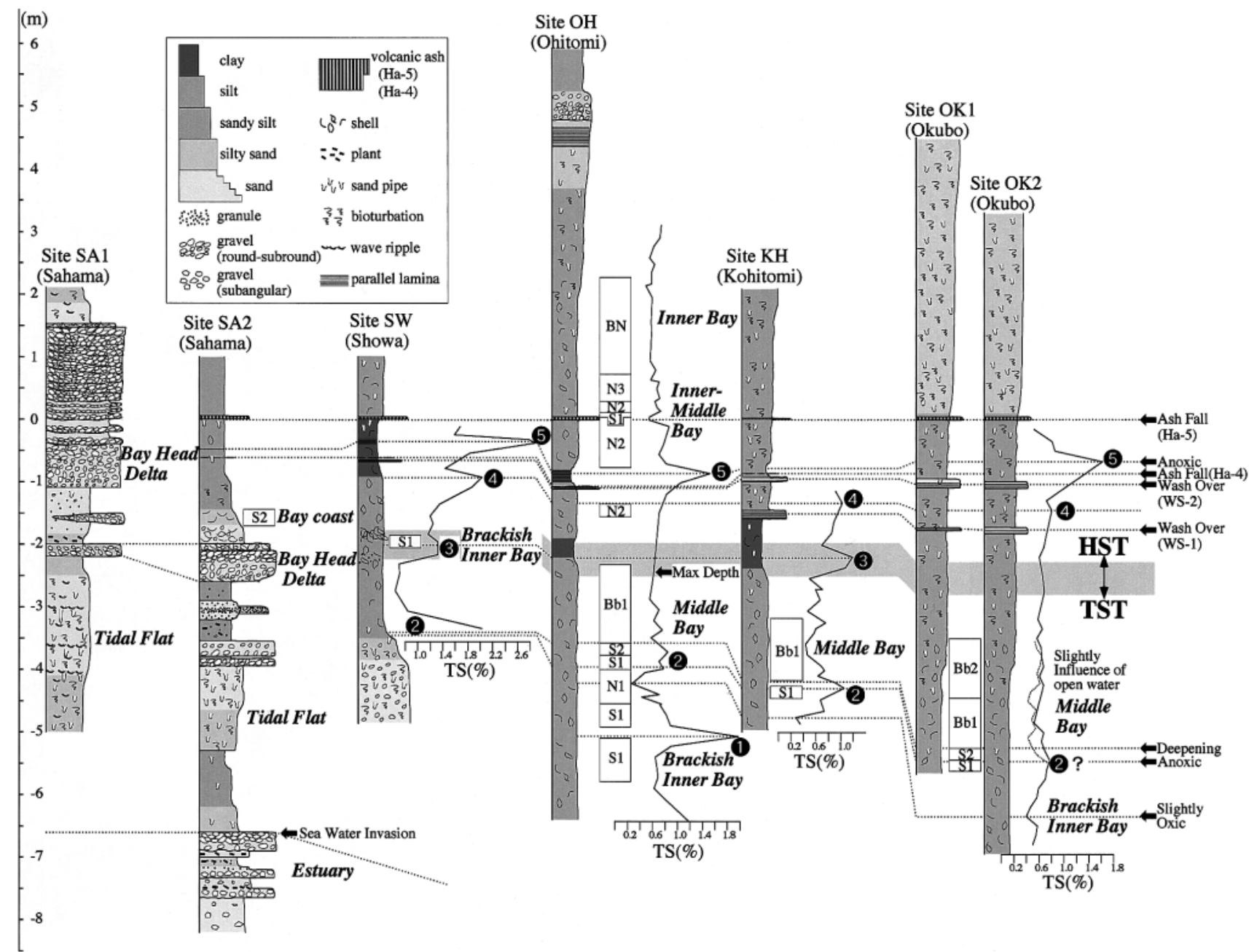

Fig.10. Variations of depositional environments in time and space. (1) to 5 mean horizons of maximum values of TS contents. TST and HST mean the transgressive systems tract and highstand systems tract, respectively.

鎖的内湾奥泥底が示唆される。層準 1 では, TOC 含有率, $\mathrm{C} / \mathrm{N}$ 比, TS 含有率とも極大を示す。また，上下の試料で貝 形虫化石の多産が見られるのに，層準 1 だけ産出しないの は，一時的により閉鎖的になり，陸上からの有機物や河川か らの栄養塩負荷量が増え, それに伴い表層の生物生産性が増 し, それらが分解されることにより, 底層は無酸素状態とな つたと推定される.

（2）層準 1 〜 2 この区間では, Sites OH で急激に TS 含 有率が減少し, C/N 比も減少する. Site KH P Site OK では 試料採取層準の最下部付近にある $\mathrm{TS}$ 含有率と $\mathrm{C} / \mathrm{N}$ 比の極小 層準がここにあたると推定される。 また，貝形虫化石相は Site $\mathrm{OH}$ でのみ認められるが, 亜化石相 S1 よりも沖合で暖 流の影響を示す亜化石相 N1へと変化している. このよう に，いずれの結果も全地点で閉鎖性が以前よりも和らぎ，若 干酸化的になり海洋プランクトン起源の有機物の増加と $N$. delicataの古浜名湾への侵入があった. すなわち，相対的海 水準の上昇が推定される.このころ Sites SA, SW では湾奥 三角州や潮汐低地がひろがる環境であった。

（3）層準 2 〜 3 Sites OH, KH, OK の層準 2 では再び,
TS 含有率, C/N 比の増加が認められる. Site OH では, 貝形 虫化石相は N1 から再び $\mathrm{S} 1$ へと変化し, $\mathrm{C} / \mathrm{N}$ 比や TS 含有率 からも閉鎖的な貧酸素環境へと逆戻りしたと推定される. 層 準 2 の直上では貝形虫化石が産出しなかった Site SW を除 き, 全ての地点で亚化石相 Bb1へと変化しており, 古浜名 湾全域で急激に古水深が増加した. Site OK では亜化石相 Bb1の上位ではB. bisanensis の他, N. delicataやS. quadriaculeata, 沿岸〜湾口部砂底・葉上種も混在し, 多 様性が最も高い亜化石相 Bb2 になっている. また, この層 準あたりから Site OK ではシルトから砂質シルトへ変化し, 堆積物の上方粗粒化がみられることを考慮すると, ここでは 外洋からの影響を受ける沿岸域から砂や貝形虫が若干運搬さ れてくるような環境に変化した. Site SW では層準 2 で急激 に上方細粒化し, シルトへと変化している. このことは, 他 地点と同様にここでも古水深の急激な増加を示唆する. 層準 (3) Site SW と Site KH でしか確認されなかった. Site OH では層準 3 はほぼ亜化石相 Bb1 の最上部にあたる粘土層に 相当すると推定され，この層準より上位ではB. bisanensis が産出しなくなることから, 古水深のピークがこの付近にあ 
ると判断され, Sites OH, KH, OK で水深が深くても $10 \mathrm{~m}$ 前 後の閉鎖的内湾中央部泥底になった。一方, Site SW では汽 水性の閉鎖的内湾奥の環境（古水深 $2 \sim 7 \mathrm{~m}$ 程度）となり, Site SA では湾奥三角州の環境になっていた.

（4）層準 3 ～層準 4 を経て層準 5 この区間での貝形虫 化石相はSite $\mathrm{OH}$ でしか認められない.ここでは層準 3 に 相当する部分より上位から B. bisanensis は全く産出しなく なり，暖かい湾奥〜中央部泥底を示唆する亜化石相 N2 とな る. 層準 4 は, Sites SW で特に顕著に認められるが, Site $\mathrm{OH}$ ではおそらく試料採取間隔がこの区間は大きいために認 められなかつた。層準 5 は試料が採取できなかつた Sites $\mathrm{SA}, \mathrm{KH}$ を除き，全ての地点で TS 含有率が Ha-4 火山灰層の 直上層準で極めて高いことから，この頃は非常に閉鎖的な内 湾中央部泥底となったことが示唆される. $\mathrm{C} / \mathrm{N}$ 比も各地で極 大值をとる.この層準には Site SW や Site $\mathrm{OH}$ では平行葉理 が顕著に発達した粘土層（LC 層）が発達しており，貝形虫 化石や有孔虫化石もこれらの LC 層からは産出しない。この ように，これらの地点では閉鎖的な環境になり，河川から運 搬される陸源性有機物の量や栄養塩負荷量が増え, 表層の生 物生産性も増加し, これらの有機物が分解されることにより 年間を通して湾底は無酸素状態になった，あるいは，河川水 の流入量の増加により塩分躍層が顕著に発達したかもしれな い.いずれにせよ底層が無酸素状態になり，その結果，硫酸 還元バクテリアの活動が盛んになつたことが予想される。一 方，より外洋側にあたる Site KH や Site OK では TOC 含有 率や TS 含有率が高いのに平行葉理層が発達していないこと から, 季節的にしか無酸素水塊が発達しなかつた場所だった と推定される.このように, この時期に古浜名湾全体が最も 閉鎖的な環境になったと推定される. Site SA2 では他地点と 同様な内湾泥底に変化したが, Site SA1 では河川の側方への 移動により, 湾奥三角州の頂置面となった。

（5）層準 5 ～最上部 層準 5 より上位の変化は Site $\mathrm{OH}$ で 顕著に認められる。貝形虫化石は亜化石相 N2 から N3 を経 て化石相 BN へ至る. TS 含有率に関しては若干減少し, 安 定するが， $\mathrm{C} / \mathrm{N}$ 比は全体的に下位よりも高い值を示す。これ らのことから，現在より強い暖流影響下で，高海水準期にお ける相対的海水準上昇速度の停滞あるいは海水準の低下によ り陸からの有機物の供給量が以前より増し, 海退により浅い 湾奥沿岸海域や河口近くへと変化したことが示唆される.

以上のように, TOC, TN, TS 分析による結果と貝形虫化石 による結果を統合したことにより，中期更新世（杉山，1991 によると酸素同位体ステージ 7 の後半）における古浜名湾の 形成初期は現在の浜名湖中央部泥底のような塩分の低い閉鎖 的な環境であったが，その後，海進が進むにつれて，現在よ りも外洋からの海水の流入量が多くなり, より深くかつ広く, 塩分も水温も現在より高い海域に変化し，無酸素水塊が広域 的に発達するような海域を経て, 海退により浅海化していつ たことがわかつた.

$$
\text { ま と め }
$$

1. 本研究では佐浜泥部層の貝形虫化石群集と TOC, TN, TS
含有率の分析結果に基づいて, 酸素同位体ステージ 7 の後半 における古浜名湾の時間的・空間的な海洋環境の変化を細か く復元することができた。 このように均質な泥質堆積物から なる地層では貝形虫化石の群集解析結果と堆積物の化学分析 結果を統合すると古水深や湾の閉鎖性に関して詳細な復元を 行えることがわかつた。

2. 海進時における古浜名湾は現在見られる浜名湖よりも外洋 からの海水の影響を多く受け，今よりも塩分が高かったと推 定される.

3. 全体的に古浜名湾の中央部は堆積初期から後期まで底層部 に季節的に極めて閉鎖的な貧〜無酸素水塊が広がる内湾で, 高海水準期に年間を通じて広域的に無酸素水塊が広がつた時 期が存在した.

4. 高海水準期の古浜名湾は, 現在西南日本に生息が限られる Bicronucythere sp.や，九州以北の日本には生息せず，南 シナ海に生息の中心を持つNeomonoceratina delicata が 卓越していた。

$$
\text { 謝辞 }
$$

島根大学総合理工学部の三瓶良和教授には CNS 分析の方 法から結果に関しての議論などをしていただいた，愛知教育 大学教育学部の星 博幸助教授, 京都大学大学院理学研究科 の増田富士雄教授, 静岡大学理学部の池谷仙之教授には野外 調査の際に堆積相，地質に関してご討論していただいた。試 料採取に関しては愛知教育大学地学教室（当時）の藤原功明 氏，丹菊香織氏，稲吉里枝氏，小関正嗣氏にお世話になった. 查読者の大妻女子大学社会情報学部の井上源喜教授および琉 球大学教育学部田吹亮一助教授には有益なご助言をいただい た．以上の方々に御礼申し上げます。本研究には文部科学省 科学研究費若手研究（B）（課題番号 13740300）および基盤 研究（C）（2）（課題番号 15540451）の一部を使用した.

$$
\text { 文献 }
$$

Abe, K., 1988, Speciation completed? In Keijella bisanensis species group. In Hanai, T., Ikeya, N. and Ishizaki, K., eds., Evolutionary Biology of Ostracoda -its Fundamentals and Applications, Kodansha and Elsevier, 919-925.

Abe, K. and Choe, K.-L., 1988, Variation of Pistocythereis and Keijella species in Gamagyang Bay, south coast of Korea. In Hanai, T., Ikeya, N. and Ishizaki, K., eds., Evolutionary Biology of Ostracoda -its Fundamentals and Applications, Kodansha and Elsevier, 367-373.

Cai, H., 1988, Ostracoda in sediments from the north continental shelf South China Sea. Tropic Oceanol., 7, 19-27. (in Chinese with English abstract)

Cai, H., 1993, A study on the palaeoecology of depositional Ostracoda in the northern and central areas of Taiwan Strait. Tropic Oceanol., 12, 71-78. (in Chinese with English abstract)

千地万造, 1964 , 浜名湖畔, 佐浜層の化石有孔虫群. 浜松市地質調查報 告書, 浜松市役所, 179-200.

Frydl, P., 1982, Holocene ostracods in the southern Boso Peninsula. In Hanai, T., ed., Studies on Japanese Ostracoda. Bull. Univ. Mus. Univ. Tokyo, no. 20, 61-140.

郷原保真・佐々木 実, 1951 , 三方が原台地の地質と地下水。資源研彙 報, 24, 45-54.

Gou, Y. X., 1990, Recent Ostracoda from Haina Island, South China Sea. Cour. Forsch.-Inst, Senckenberg, 123, 19-36.

Hanai, T., Ikeya, N., Ishizaki, K., Sekiguchi, Y. and Yajima, M., 1977, Check- 
list of Ostracoda from Japan and its adjacent seas. University of Tokyo Press, 119p.

Horn, H. S., 1966, Measurement of "overlap” in comparative ecological studies. Amer. Natur., 100, 419-424.

星 博幸・亀井春美, 2003 , 陸上に露出する無層理堆積物の初磁化率 (帯磁率) による対比: 静岡県, 更新統佐浜泥部層の例. 地質雑, 109, 697-709.

Ikeya, N. and Hanai, T., 1982, Ecology of Recent ostracods in the Hamanako region, the Pacific coast of Japan. In Hanai, T., ed., Studies on Japanese Ostracoda. Bull. Univ. Mus. Univ. Tokyo, no. 20, 15-59.

池谷仙之・塩崎正道, 1993, 日本沿岸内湾性介形虫類の特性一古環境解 析の指標として一。地質学論集, no. 39, 15-32.

池谷仙之・和田秀樹 - 阿久津 浩 - 高橋 実, 1990 , 浜名湖の起源と地 史的変遷. 地質学論集, no. 36, 129-150.

入月俊明・藤原 治・布施圭介・増田富士雄, 1998 , 神奈川県三浦半島 西岸の後水期における古環境変遷 : ボーリングコア中の貝形虫化 石群集とイベント堆積物. 化石, no. 64, 1-22.

入月俊明・細山光也, 2000 , 愛知県の更新統野間層から産出した内湾生 貝形虫 (甲殼類) 化石. 愛知教育大研報 (自然科学) , 49, 9-15.

入月俊明・稲吉里枝 - 石崎国熙 - 安原盛明, $2002 \mathrm{a}$, 第四紀の地史的事 件と関連した日本産内湾性貝形虫種の消長と形態変化. 日本地質 学会第 109 年学術大会講演要旨, 145.

入月俊明・神谷美保・植田景子, $2002 b$, 渥美半島中部更新統田原層の 貝形虫化石群集と堆積相の時空分布. 島根大地球資源環境学研 報, no. 21, 31-39.

入月俊明 - 増田富士雄 - 池谷仙之, $2003 \mathrm{a}$, 静岡県浜松市佐浜町のナウ マンゾウ発掘調査地における中部更新統浜松層の堆積相と貝形虫 化石. 静岡地学, no. 87, 1-13.

Irizuki, T., Masuda, F., Miyahara, B., Hirotsu, A., Ueda, S. and Yoshikawa, S., 2001, Vertical changes of Holocene ostracodes in bore hole cores from off Kobe, related to the opening of straits and relative sea-level change in western Japan. Quatern. Res., 40, 105-120.

入月俊明・ 中村雄三・高安克己・坂井三郎, $2003 \mathrm{~b}$, 中海における過去 約 40 年間の貝形虫 (甲殼類) の群集変化. 島根大地球資源環境 学研報, no. 22, 149-160.

Ishizaki, K., 1968, Ostracodes from Uranouchi Bay, Kochi Prefecture, Japan, Sci. Rep. Tohoku Univ., Second Ser. (Geol.), 40, 1-45.

Ishizaki, K., 1971, Ostracodes from Aomori Bay, Aomori Prefecture, Northeast Honshu, Japan. Sci. Rep. Tohoku Univ., Second Ser. (Geol.) , 43, 59-97.

Ishizaki, K. and Kato, M., 1976, The basin development of the Diluvium Furuya Mud Basin, Shizuoka Prefecture, Japan, based on faunal analysis of fossil ostracodes. In Takayanagi, Y. and Saito, T., eds., Progress in Micropaleontology, Micropaleontology Press, 118-143.

磯見 博 - 井上正昭, 1972, 浜松地域の地質. 地域地質研究報告（5 万 分の 1 地質図幅), 地質調査所, 35p.

伊藤広光, 1998a, サロマ湖および網走湖の貝形虫相. 日本古生物学会 1998 年年会予稿集, 128.

伊藤広光, $1998 b, 1996$ 年浜名湖調査試料から得られた貝形虫群集. LAGUNA (汽水域研究), 5, 93-99.

岩崎泰頴, 1992 , 熊本平野地下における有明粘土層中の介形虫の群集変 化. 熊本大理紀要 (地学), 13, 1-12.

小林国夫, 1942 , 浜名湖畔の洪積層. 地質雑, 49, 326-331.

小林国夫, 1964, 浜松市の地質. 浜松市地質調査報告書, 浜松市役所, 3165.

粉川昭平, 1964 , 浜松市付近の植物遺体. 浜松市地質調査報告書, 浜松 市役所, 203-247.

倉門由紀子 - 三瓶良和 - 高安克己・徳岡隆夫 - 井内美郎, 1998, 中海お よび浜名湖表層堆積物の有機炭素・窒素・ イオウ濃度分布. LAGUNA (汽水域研究), 5, 123-135.

Makiyama, J., 1924, Notes on a fossil elephant from Sahama, Totomi, Mem. Coll. Sci. Kyoto Imp. Univ., Ser. B, 1, 255-264.

Masuda, F., Irizuki, T., Fujiwara, O., Miyahara, B. and Yoshikawa, S., 2002, A Holocene sea-level curve constructed from a single core at Osaka, Japan (A preliminary note).Mem. Fac. Sci. Kyoto Univ., Ser. Geol. \&Mineral., 59, 1-8.

南 秀樹 · 加藤義久 ・ 和田秀樹 - 岡部史郎, 1995 , 浜名湖の堆積物コア 中の元素の分布と過去 1 万年間の環境変遷. 地球化学, 29, 85-97.

武藤鉄司, 1987, 天竜川下流地方, 三方が原・磐田原台地の地質一現在
の開析扇状地からの解釈一。地質雑, 93, 259-273

中井信之・太田友子・藤澤 寛・吉田正夫, 1982 , 堆積物コアの炭素同 位体比, $\mathrm{C} / \mathrm{N}$ 比および $\mathrm{FeS}_{2}$ 含有量からみた名古屋港周辺の古気候, 古海水準変動. 第四紀研究, 21, 169-177.

中尾賢一, 1993, 宮崎平野の更新統・通山浜層の貝類群集の分布と変 遷. 第四紀研究, 32, 157-170.

延原尊美, 2003, 静岡県浜松市佐浜町のナウマンゾウ発掘調査において 得られた中部更新統浜松層産貝化石. 静岡地学, no. 87, 41-51.

野嶋宏二・池谷仙之・田中源吾, 2003, 浜名湖周辺地域産出のナウマン ゾウ化石. 静岡地学, no. 87, 23-32.

Okubo, I., 1975, Callistocythere pumila Hanai, 1957 and Leguminocythereis bisanensis sp. nov. in the inland sea, Japan (Ostracoda). Proc. Japan. Soc. Syst. Zool., 11, 23-31

三瓶良和・倉門由紀子・清水 紋・高安克己・石田 聖, 1997, サロマ 湖・網走湖底質の有機炭素・窒素・ イオウ濃度. Res. Org. Geochem., 12, 51-60,

Sampei, Y., Matsumoto, E., Kamai, T. and Tokuoka, T., 1997, Sulfur and organic carbon relationship in sediments from coastal brackish lakes in the Shimane Peninsula district, southwest Japan. Geochem. Jour., 31, 245-262.

杉山雄一, 1991, 渥美半島一浜名湖東岸地域の中部更新統一海進一海退 堆積サイクルとその広域対比一。地調月報, 42, 75-109.

高橋啓一・松岡廣繁・樽 創・安井謙介・長谷川善和, 2003, 佐浜ナウ マンゾウ発掘調査で産出した脊椎動物化石について. 静岡地学, no. $87,15-21$.

Takai, F. and Tsuchi, R., 1959, Notes on the fossil elephant recently found in the Sahama Mud, Shizuoka Prefecture Japan. Quatern. Res., 1, 164-173.

高安克己・植田和昭 - 太田久子, 1990 , 中海 - 宍道湖の自然史研究一そ の 12 . 中海底質中の介形虫遺骸群集とその変遷一. 島根大地質 学研報, 9, 129-144.

土 隆一, 1960 , 天竜川下流地方第四系の地史学的考察. 東北大理科報 告特別号 (半沢記念号), 4, 583-589.

Whatley, R. and Zhao, Q., 1987, Recent Ostracoda of the Malacca Straits Part I. Revista Esp. Micropaleont., 19, 327-366.

Whatley, R. and Zhao, Q., 1988, Recent Ostracoda of the Malacca Straits Part II. Revista Esp. Micropaleont., 20, 5-37.

Yajima, M., 1978, Quaternary Ostracoda from Kisarazu near Tokyo. Trans. Proc. Palaeont. Soc. Japan, N. S., no. 112, 371-409.

Yajima, M., 1982, Late Pleistocene Ostracoda from the Boso Peninsula, central Japan. In Hanai, T., ed., Studies on Japanese Ostracoda. Bull. Univ. Mus. Univ. Tokyo, no. 20, 141-228.

Yasuhara, M. and Irizuki, T., 2001, Recent Ostracoda from the northeastern part of Osaka Bay, southwestern Japan. Jour. Geosci. Osaka City Univ., 44, 57-95.

Yasuhara, M., Irizuki, T., Yoshikawa, S. and Nanayama, F., 2002a, Changes in Holocene ostracode faunas and depositional environments in the Kitan Strait, southwestern Japan. Paleont. Res., 6, 85-99.

Yasuhara, M., Irizuki, T., Yoshikawa, S. and Nanayama, F., 2002b, Holocene sea-level changes in Osaka Bay, western Japan: ostracode evidence in a drilling core from the southern Osaka Plain. Jour. Geol. Soc. Japan, 108, 633-643.

吉川博章, 2000 , オニグルミの堅果化石に残つたアカネズミの食痕一静 岡県浜松市の中期更新世佐浜泥層からの産出. 豊橋市自然史博研 報, no. 10, 23-30.

吉川博章, 2002 , 静岡県浜松市の中部更新統流路埋積堆積物中の大型植 物化石. 豊橋市自然史博研報, no. 12, 9-15.

吉川博章, 2003 , 静岡県浜松市佐浜のナウマンゾウ発掘地から産出した 大型植物化石. 静岡地学, no. 87, 33-37.

Zhao, Q. and Wang, P., 1988, Distribution of modern ostracods in the shelf seas off China. In Hanai, T., Ikeya, N. and Ishizaki, K., eds., Evolutionary Biology of Ostracoda - its Fundamentals and Applications, Kodansha and Elsevier, 805-821.

Zhao, Q., Wang, P. and Zheng, Q., 1985, Ostracoda in bottom sediments of the South China Sea off Guangdong Province, China: Their taxonomy and distribution. In Wang, P., ed., Marine Micropaleontology of China, China Ocean Press, Beijing, 229-255.

Zhao, Q. and Whatley, R., 1988, The genus Neomonoceratina (Crustacea: Ostracoda) from the Cainozoic of the West Pacific margins, 
Acta Oceanol. Sinica, 7, 562-577.

Zhao, Q. and Whatley, R., 1989, Recent podocopid Ostracoda of the Sedili
River and Jason Bay, southeastern Malay Peninsula. Micropaleontology, 35, 168-187.

(要 旨)

入月俊明・瀬戸浩二, 2004, 中期更新世の古浜名湾における古環境の時間的・空間的変 化一貝形虫化石群集と全有機炭素・全窒素・全イオウ分析結果一。地質雑, 110, 309-

324. (Irizuki, T. and Seto, K.,2004, Temporal and spatial variations of paleoenvironments of Paleo-Hamana Bay, central Japan, during the Middle Pleistocene -Analyses of fossil ostracode assemblages, and total organic carbon, total nitrogen and total sulfur contents.Jour. Geol. Soc. Japan, 110, 309-324.)

中期更新世の古浜名湾の古環境を詳細に復元するため, 浜松層の佐浜泥部層が露出する 4 地点において貝形虫化石群集, 全有機炭素, 全窒素および全イオウ含有率 (CNS 元素分 析）についての高分解能解析を行った．貝形虫化石に関しては 26 種が得られたが，この うちの 5 種の合計で全体の $98.3 \%$ に達する. 貝形虫化石と CNS 元素分析結果に基づく と, 古浜名湾は海進初期には汽水性の浅い閉鎖的内湾で，底層には貧酸素水塊が発達した。 その後, 暖流が広く流入し湾はわずかに酸化的となった，急速な海水準上昇に伴い，再び 湾は閉鎖的になり $10 \mathrm{~m}$ 前後の水深に達した。高海水準期初期には湾は極めて閉鎖的にな り広い範囲で底層に無酸素水塊が発達した。 その後, 湾は今日の浜名湖よりも暖かい水塊 のもとで浅海化していった．このように，中期更新世の古浜名湾はほとんど閉鎖的な内湾 であり, 海進期と高海水準期には現在の浜名湖よりも塩分が高かったと推定される. 